\title{
TEF, a transcription factor expressed specifically in the anterior pituitary during embryogenesis, defines a new class of leucine zipper proteins
}

\author{
Daniel W. Drolet, ${ }^{1,2}$ Kathleen M. Scully, ${ }^{1,2}$ Donna M. Simmons, ${ }^{3}$ Michael Wegner, ${ }^{1}$ Keting Chu, ${ }^{4}$ \\ Larry W. Swanson, ${ }^{3}$ and Michael G. Rosenfeld ${ }^{1}$ \\ ${ }^{1}$ Eukaryotic Regulatory Biology Program and Howard Hughes Medical Institute, University of California, San Diego, La \\ Jolla, California 92093-0648 USA ${ }^{2}$ Biomedical Sciences Graduate Program, La Jolla, California 92093-0648 USA; ${ }^{3}$ University \\ of Southern California, Department of Biological Sciences, Section of Neurobiology, Los Angeles, California 90089-2520 \\ USA; ${ }^{4}$ Department of Microbiology and Immunology, University of California, San Francisco, California 94143 USA
}

\begin{abstract}
We have identified and characterized a new member of the leucine zipper (bZlP) gene family of transcription factors, thyrotroph embryonic factor (TEF). Analysis of the ontogeny of TEF gene expression reveals the presence of TEF transcripts, beginning on embryonic day 14, only in the region of the rat anterior pituitary gland in which thyrotrophs arise. This pattern of gene expression corresponds temporally and spatially to the onset of thyroid-stimulating hormone (TSH $\beta$ ) gene expression, which defines the thyrotroph phenotype. Coupled with this observation, we find that TEF can bind to and trans-activate the TSH $\beta$ promoter. In contrast to this restricted pattern of expression during embryogenesis, TEF transcripts appear in several tissues in the mature organism. We propose that TEF belongs to a new class of bZIP proteins on the basis of the unique homology between TEF and another member of the bZIP gene family, the albumin D box-binding protein (DBP). TEF and DBP transcripts are coexpressed in a pituitary cell line, and these two proteins can readily form heterodimers. The DNA-binding and dimerization domains of TEF correspond to those found in other bZIP proteins. We have however, identified a cluster of basic amino acids, found only in TEF and DBP, that is necessary for the proper DNA-binding site specificity of TEF. A major trans-activation domain of TEF resides outside the region of homology to other bZIP proteins. These data are consistent with a role for a member of a new class of bZIP transcription factors in activating gene expression in the developing thyrotroph.
\end{abstract}

[Key Words: TEF; pituitary; TSH $\beta$ promoter: transcription factor; DNA-binding protein]

Received June 10, 1991; revised version accepted July 19, 1991

The mammalian anterior pituitary gland provides an excellent model system in which to study the initiation and regulation of cell type-specific gene expression within an organ. The anterior pituitary gland arises from an infolding of somatic ectoderm, referred to as Rathke's pouch (Schwind 1928), which generates five phenotypically distinct cell types distinguished by the trophic hormone they express. In rats, these cell types appear in a distinct temporal and spatial pattern (Simmons et al. 1990). Thyrotrophs and corticotrophs, which express thyroid-stimulating hormone (TSH $\beta$ ) and POMC, respectively, are the first phenotypically distinct cell types to appear [embryonic day 14 (e14)]; and somatotrophs and lactotrophs, which express growth hormone and prolactin respectively, are the last to appear [embryonic days 16-17 (e16-e17)]. The pituitary-specific transcription factor Pit-1 (Bodner et al. 1988; Ingraham et al. 1988) is expressed in somatotrophs, lactotrophs, and thyro- trophs and has been shown to be necessary for prolactin and growth hormone gene expression (Li et al. 1990). Pit-l is also required for the presence of thyrotrophs in the mature animal (Li et al. 1990) even though detectable levels of Pit-1 gene expression initially appear in the pituitary long after the establishment of TSH $\beta$ gene expression (Simmons et al. 1990).

Here, we report the identification and characterization of thyrotroph embryonic factor (TEF), a transcription factor expressed in the developing anterior pituitary gland. We propose that TEF and the albumin $\mathrm{D}$ box-binding protein (DBP) (Mueller et al. 1990), which share a unique region of homology, constitute a new class of bZIP transcription factors. The bZIP family is characterized by a conserved DNA-binding domain, containing clusters of basic amino acids, immediately adjacent to a conserved dimerization domain. The dimerization domain consists of a helical region of $\sim 30$ amino acids usually containing 
a leucine residue at every seventh position, the leucine zipper motif. Compatible dimerization sequences fold as parallel coiled coils, resulting in the formation of homodimeric or heterodimeric proteins. These protein dimers contain a bipartite DNA-binding domain formed by the conserved basic region from each subunit (Kouzarides and Ziff 1988; Landschulz et al. 1988a,b, 1989; Sassone-Corsi et al. 1988; Gentz et al. 1989; O'Shea et al. 1989; Ransone et al. 1989; Turner and Tiian 1989; Oas et al. 1990). The bZIP gene family has been subdivided into several distinct classes on the basis of the primary amino acid homology, the DNA-binding specificity, and the compatibility of the leucine zipper dimerization domain among members of each class. Included among these are the Fos-Jun (for review, see Busch and Sassone-Corsi 1990|, CAMP response element binding-activating transcription factor (CREB-ATF) (Hai et al. 1989; for review, see Ziff 1990), and CCAAT/ enhancer-binding protein (C/EBP) (Akira et al. 1990; Descombes et al. 1990; Poli et al. 1990; Roman et al. 1990) classes. The alternative formation of homodimers or heterodimers within or between members of each class, in response to environmental or developmental stimuli, is believed to be important in the regulation of gene expression (for review, see Jones 1990; Busch and Sassone-Corsi 1990|. In this regard, we demonstrate that TEF and DBP transcripts are coexpressed in the GC cell line and that these two proteins can readily form heterodimers.

Here, we also report that during embryogenesis, TEF transcripts are detectable only in the region in which nascent thyrotrophs emerge in the anterior pituitary gland. Furthermore, the initiation of TEF gene expression is coincident with the initial expression of the $\beta$-subunit of thyroid-stimulating hormone (TSH $\beta$ ). In combination with these observations, we show that TEF can trans-activate the TSH $\beta$ promoter. These results are consistent with a role for a member of a new class of bZIP proteins, TEF, in the trans-activation of TSH $\beta$ gene expression in the nascent thyrotroph.

\section{Results}

\section{Cloning of TEF}

Although Pit-1 is required for the trans-activation of prolactin (Ingraham et al. 1988) and growth hormone gene expression (Bodner et al. 1988; Ingraham et al. 1988), it alone cannot explain the regulation or restriction of cell type-specific gene expression in somatotrophs, lactotrophs, or thyrotrophs. The prolactin-1P (Prl-1P) pituitary-specific cis-active element (Nelson et al. 1988), which mediates regulation by epidermal growth factor (EGF) and phorbol esters (Elsholtz et al. 1986), was used to screen for additional trans-acting factors that regulate gene expression in the pituitary. Two phage $\lambda$ cDNA expression libraries, one derived from rat pituitary and the other from a rat pituitary cell line $(G C)$, were screened for the ability of clones to bind the Prl-1P element of the prolactin promoter as described previously
(Ingraham et al. 1988). A single phage was isolated that produced a fusion protein capable of binding to the Prl$1 P$ element but not to a Pit-1-binding element in the growth hormone promoter (West et al. 1987; Nelson et al. 1988). Nucleotide sequencing of the 4.0-kb cDNA derived from this phage revealed a long open reading frame in register with the fused $\beta$-galactosidase-coding sequence. The first ATG codon present in this frame, located 37 nucleotides downstream from the fusion point, was tentatively assigned as the initiation codon, although TEF may contain additional amino-terminal information. Four additional clones, obtained from the pituitary cDNA library, contained identical sequences, confirming the predicted amino acid sequence of TEF. The open reading frame codes for a polypeptide of 261 amino acids with a predicted mass of $29.3 \mathrm{kD}$.

As shown in Figure 1B, TEF is a member of the bZIP family of transcription factors and is related most closely to the bZIP protein DBP (Mueller et al. 1990, U. Schibler, pers. comm.). DBP is enriched in the liver and can bind to and trans-activate the albumin gene promoter (Mueller et al. 1990). The TEF-DBP homology (T + D homologyl not only consists of the basic and leucine zipper motifs characteristic of the bZIP family but also a 52amino-acid region unique to TEF and DBP. This latter region is rich in the amino acids proline, glutamate, and aspartate, and is referred to as the PAR region (proline and acidic rich). The basic and leucine zipper domains of TEF and $\mathrm{DB} P$ are highly related to each other, with $81 \%$ and $55 \%$ identity, respectively. Among the other known bZIP proteins, the amino acid sequence of TEF is most closely related to c-Fos $(40 \%$ identity within the basic and leucine zipper regions).

\section{TEF gene expression is restricted to pituitary thyrotrophs during ontogeny}

To gain insight into a possible role for TEF in pituitary development, in situ hybridizations were performed with radiolabeled TEF antisense RNA probes and midsagittal sections through the rat anterior pituitary gland from embryonic days 11-16 (e11-16) of development. No hybridization was observed on e11, e12, or e13 (data not shown). However, on e14, TEF transcripts were detected only in a small rostral part of the anterior pituitary gland corresponding to the precise area of thyrotroph development (Fig. 2). This pattern of gene expression corresponds temporally as well as spatially to the reported pattern of TSH $\beta$ gene expression (Simmons et al. 1990), which defines the thyrotroph phenotype. To confirm these observations, the pattern of TSH $\beta$ gene expression was analyzed in sections serial to those described above. $\mathrm{TSH} \beta$ transcripts were detected in a pattern identical both spatially and temporally to the pattern observed for TEF gene expression (Fig. 2). This restricted pattern of TEF gene expression was maintained on el6 (Fig. 2). Microscopic examination of multiple whole embryonic midsagittal and parasagittal sections from el4 did not detect TEF transcripts in any organ or tissue other than the thyrotrophs (data not shown). 
A

\begin{tabular}{|c|c|c|c|c|c|c|c|c|c|c|c|c|c|c|c|}
\hline & & & & & & & & $\begin{array}{c}\text { A TG } \\
\text { Met }\end{array}$ & $\underset{\text { Gilu }}{\mathrm{GAG}}$ & $\begin{array}{l}A C \\
\text { Asn }\end{array}$ & $\begin{array}{c}\text { CCC } \\
\text { Pro }\end{array}$ & $\begin{array}{c}\text { CCG } \\
\text { Pro }\end{array}$ & $\begin{array}{c}C G C \\
\text { Arg }\end{array}$ & $\begin{array}{c}\text { GA G } \\
\text { G/U }\end{array}$ & $\begin{array}{r}21 \\
7\end{array}$ \\
\hline C & $\begin{array}{l}G G \\
\text { Arg }\end{array}$ & $\begin{array}{l}\text { TC } \\
\text { Leu }\end{array}$ & $A T$ & $A G$ & A & $\begin{array}{l}A G \\
\text { Lys }\end{array}$ & $\begin{array}{c}\text { GGG } \\
\text { Gly }\end{array}$ & $\begin{array}{l}\mathrm{AAG} \\
\text { Lys }\end{array}$ & $\begin{array}{l}G A A \\
\text { Glu }\end{array}$ & $\begin{array}{l}\mathrm{AAG} \\
\text { Lys }\end{array}$ & $\begin{array}{c}\text { CTG } \\
\text { Leu }\end{array}$ & $\begin{array}{c}\text { GAG } \\
\text { Giu }\end{array}$ & $\begin{array}{c}\text { GAA } \\
\text { G/u }\end{array}$ & $\begin{array}{l}A C \\
\text { Asp }\end{array}$ & $\begin{array}{l}66 \\
n^{2}\end{array}$ \\
\hline 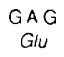 & 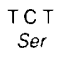 & Ala & Ala & & & & G & & C & & ${ }_{a}^{C}$ & $\begin{array}{c}\text { TC C } \\
\text { Ser }\end{array}$ & $\begin{array}{l}\text { C T C } \\
\text { Leu }\end{array}$ & $\begin{array}{l}\text { TG } \\
\text { Met }\end{array}$ & $\begin{array}{l}11 \\
37\end{array}$ \\
\hline Pro & ro & He & & & & & $\begin{array}{c}\text { A T C } \\
\text { He }\end{array}$ & & $\begin{array}{c}\text { TAC } \\
\text { Tyr }\end{array}$ & T & $\begin{array}{l}\text { GGC } \\
\text { Gly }\end{array}$ & $\begin{array}{l}A A G \\
G / u\end{array}$ & $\begin{array}{l}\text { TC T } \\
\text { Ser }\end{array}$ & $\begin{array}{l}\text { T T C } \\
\text { Phe }\end{array}$ & 56 \\
\hline . & $u$ & $\begin{array}{c}\text { GA G } \\
\text { Glu }\end{array}$ & $T_{y r}$ & & c & & $\begin{array}{c}\text { G A T } \\
\text { Asp }\end{array}$ & $G$ & $\begin{array}{l}\text { T T C } \\
\text { Phe }\end{array}$ & $\begin{array}{c}\text { C T G } \\
\text { Leu }\end{array}$ & $\begin{array}{l}\text { T T G } \\
\text { Leu }\end{array}$ & $\begin{array}{l}\text { BA G } \\
\text { Glu }\end{array}$ & $\begin{array}{c}\text { A A T } \\
\text { Asn }\end{array}$ & $\begin{array}{l}\text { GC } \\
\text { Gly }\end{array}$ & \\
\hline TC & 1 & $\mathrm{CC}$ & & & $\mathrm{CC}$ & & $\begin{array}{l}\text { C T G } \\
\text { Leu }\end{array}$ & $A$ & $\begin{array}{c}\text { CA G } \\
\text { Gln }\end{array}$ & $\begin{array}{c}A A C \\
\text { Asn }\end{array}$ & $\begin{array}{l}\text { CTG } \\
\text { Leu }\end{array}$ & $\begin{array}{l}\text { CTG } \\
\text { LeU }\end{array}$ & $\begin{array}{l}\text { C TG } \\
\text { Leu }\end{array}$ & & \\
\hline io & $\begin{array}{l}\text { CA } \\
\text { Ala }\end{array}$ & $\begin{array}{l}\text { A G } \\
\text { Glu }\end{array}$ & & $A G$ & $G$ & & $\begin{array}{c}G A G \\
G / u\end{array}$ & $S$ & $\begin{array}{c}G C C \\
\text { Ala }\end{array}$ & $\begin{array}{c}\text { A GC } \\
\text { Ser }\end{array}$ & $\begin{array}{l}\mathrm{TCT} \\
\text { Ser }\end{array}$ & $\begin{array}{l}\text { TCC } \\
\text { Ser }\end{array}$ & & $\begin{array}{l}\text { SCA } \\
\text { Ala }\end{array}$ & \\
\hline $\begin{array}{l}C A \\
\text { Ser }\end{array}$ & $\begin{array}{l}\text { CA } \\
\text { Pro }\end{array}$ & $\begin{array}{l}\text { CA } \\
\text { Pro }\end{array}$ & $\begin{array}{l}\text { C } \\
\text { Ser }\end{array}$ & $\begin{array}{c}\text { TC } \\
\text { Se }\end{array}$ & $\begin{array}{l}\text { TCT } \\
\text { Ser }\end{array}$ & $\begin{array}{c}\text { AC T } \\
T h r\end{array}$ & $\begin{array}{c}\text { GCC } \\
\text { Ala }\end{array}$ & II & $\begin{array}{l}\text { T T C } \\
\text { Phe }\end{array}$ & $\begin{array}{c}C A G \\
G i n\end{array}$ & $\begin{array}{c}\text { C C C } \\
\text { Pro }\end{array}$ & $\begin{array}{c}\text { TC G } \\
\text { Ser }\end{array}$ & $\begin{array}{c}\text { GAA } \\
\text { Glu }\end{array}$ & & \\
\hline 10 & $\begin{array}{c}\text { TCC } \\
\text { Ser }\end{array}$ & $\begin{array}{c}\text { A GC } \\
\text { Ser }\end{array}$ & $\begin{array}{l}A C A \\
T h r\end{array}$ & $\begin{array}{r}\text { G A } \\
\text { Glu }\end{array}$ & $\begin{array}{c}\text { TCA } \\
\text { Ser }\end{array}$ & $\begin{array}{l}\mathrm{TC} \\
\mathrm{Se}\end{array}$ & $\begin{array}{c}\text { T TG } \\
\text { Leu }\end{array}$ & Glu & $\begin{array}{c}\text { A A G } \\
\text { Lys }\end{array}$ & $\begin{array}{c}\text { G A G } \\
\text { Glu }\end{array}$ & $\begin{array}{c}\text { A GG } \\
\text { Arg }\end{array}$ & Glu & $\begin{array}{c}\text { ACA } \\
\text { Thr }\end{array}$ & $\begin{array}{c}\text { CCA } \\
\text { Pro } \\
\end{array}$ & \\
\hline GT & $\begin{array}{c}\text { CCC } \\
\text { Pro }\end{array}$ & $\begin{array}{c}\text { A T C } \\
\text { He }\end{array}$ & $\begin{array}{c}G A \\
A S P\end{array}$ & C & $A C$ & & $\begin{array}{c}\text { G TG } \\
\mathrm{Val}\end{array}$ & $G$ & $\begin{array}{c}\text { G T T } \\
V_{a l}\end{array}$ & $T$ & $\begin{array}{c}\mathrm{GTG}_{\mathrm{Val}} \\
\mathrm{V}\end{array}$ & $\begin{array}{c}A A C \\
A s n\end{array}$ & $\begin{array}{c}\text { T T C } \\
\text { Phe }\end{array}$ & $\begin{array}{l}\text { A A T } \\
\text { Asn }\end{array}$ & \\
\hline$C T$ & $\begin{array}{l}\text { AC } \\
\text { Asp }\end{array}$ & $C T$ & C T & A & 3 & TC & $\begin{array}{c}\text { C T C } \\
\text { Leu }\end{array}$ & $\begin{array}{c}\mathrm{TC} \\
\mathrm{Se}\end{array}$ & $\begin{array}{l}A G T \\
\text { Ser }\end{array}$ & $\begin{array}{l}\text { T A } \\
\text { Val }\end{array}$ & $\begin{array}{l}\text { CA A } \\
\text { Pro }\end{array}$ & $\begin{array}{l}\text { בG T } \\
\text { Gly }\end{array}$ & $\begin{array}{l}\text { SGG } \\
\text { Gly }\end{array}$ & $\begin{array}{c}\text { GAA } \\
\text { Glu }\end{array}$ & \\
\hline $\mathrm{T}$ & $\begin{array}{c}\text { TTC } \\
\text { Phe }\end{array}$ & $\begin{array}{c}\text { A A C } \\
\text { Asn }\end{array}$ & $\mathrm{C}$ & $G$ & $A G$ & C & $\begin{array}{c}\text { A A G } \\
\text { tys }\end{array}$ & $\begin{array}{l}\text { T T } \\
\text { Ph }\end{array}$ & $\begin{array}{c}\text { GCA } \\
A / a\end{array}$ & G & $\begin{array}{c}\text { GAA } \\
\text { G/u }\end{array}$ & $\begin{array}{c}G A C \\
A S p\end{array}$ & $\begin{array}{c}\text { CT G } \\
\text { Leu }\end{array}$ & Lys & \\
\hline $\begin{array}{l}\mathrm{CC} \\
\text { Pro }\end{array}$ & $\begin{array}{c}C A G \\
G / n\end{array}$ & $\begin{array}{c}\text { CC T } \\
\text { Pro }\end{array}$ & G & C & 3 & & $\begin{array}{c}\text { GCC } \\
\text { Ala }\end{array}$ & L) & $\begin{array}{c}\text { AAA } \\
\text { Lys }\end{array}$ & $\begin{array}{c}\text { G T C } \\
\text { Val }\end{array}$ & $\begin{array}{l}\text { T T T } \\
\text { Phe }\end{array}$ & $\begin{array}{l}\text { GT C } \\
\text { Val }\end{array}$ & $\begin{array}{l}\text { CC T } \\
\text { Pro }\end{array}$ & Asp & \\
\hline$A G$ & $\begin{array}{l}C A G \\
G \text { in }\end{array}$ & $A G$ & & & G & & $T G G$ & A & G & $\Delta T$ & $\begin{array}{l}A G \\
y s\end{array}$ & $\begin{array}{l}A G \\
y s\end{array}$ & C & T & \\
\hline$T G$ & $\begin{array}{c}G C A \\
A / a\end{array}$ & $\mathrm{Cr}$ & $A \mathrm{~A}$ & & C & & $\begin{array}{l}A C \\
\text { Asp }\end{array}$ & C & $\mathrm{G}$ & $\mathrm{C}$ & $\begin{array}{l}T G \\
\text { Leu }\end{array}$ & $\begin{array}{l}A G \\
\text { Lys }\end{array}$ & $\begin{array}{c}\text { GA G } \\
\text { Glu }\end{array}$ & $\begin{array}{l}\top \\
n\end{array}$ & \\
\hline A G & $\begin{array}{l}\text { TC } \\
\text { Ile }\end{array}$ & $\begin{array}{c}\text { ACC } \\
T h r\end{array}$ & TC & & A & & $T T$ & c & G & $G$ & $\begin{array}{l}A G \\
\text { Glu }\end{array}$ & $\begin{array}{l}A C \\
A s n\end{array}$ & $\begin{array}{l}\text { CA } \\
T h r\end{array}$ & C & \\
\hline T & $\begin{array}{c}C G C \\
\text { Arg }\end{array}$ & $\begin{array}{c}A C G \\
T h r\end{array}$ & & & Ats & & $\begin{array}{l}\text { T T } \\
\text { teu }\end{array}$ & $\begin{array}{c}C C \\
A r\end{array}$ & G & G & $\begin{array}{c}G T G \\
\mathrm{Val}\end{array}$ & $\begin{array}{c}\text { GGC } \\
\text { Gly }\end{array}$ & $\begin{array}{l}A A G \\
\text { Lys }\end{array}$ & $\begin{array}{l}\text { TGC } \\
\text { Cys }\end{array}$ & \\
\hline $\begin{array}{l}\text { AG } \\
\text { Lys }\end{array}$ & Thr & $11 e$ & Vai & $\mathrm{Se}$ & Ly & Ty & Glu & Th & $L y$ & $T y{ }^{\prime}$ & Gly & Pro & Leu & * & \\
\hline
\end{tabular}

B

\section{T+D HOMOLOGY}

PAR Region

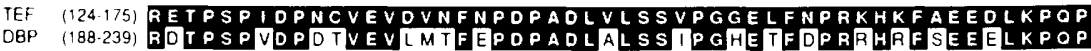

DNA Binding Domain
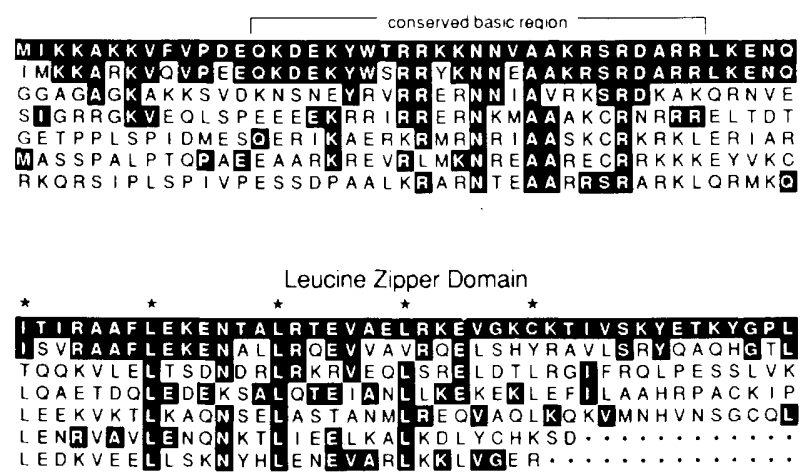

Figure 1. Nucleotide and deduced amino acid sequence of TEF and homology to the bZIP gene family. (A) Five independent clones obtained from rat pituitary and rat pituitary cell (GC) cDNA libraries were sequenced as described in Materials and methods. The region of sequence homology between TEF and DBP is underlined; the portion of TEF homologous to other members of the leucine zipper gene family is in boldface type. $(B)$ Homology between TEF and other members of the bZIP family. The region of homology between TEF and DBP ( $T+D$ homology) is subdivided into a PAR region unique to these two bZIP proteins $(67 \%$ identity); a DNAbinding domain (81\% identity); and a leucine zipper domain $(51 \%$ identity). TEF DNA-binding and leucine zipper domains are also compared to sequences from other members of the bZIP family. All sequences shown are derived from rat except GCN4, and each is marked with the name of the protein and the coordinates of the first and last amino acids shown per line. C/EBP (Landschulz et al. 1988a,b); c-Fos (Curran et al. 1987); c-Jun (Sakai et al. 1989); CREB (Gonzalez et al. 1989); GCN4 (Vogt et al. 1987). TEF shares $40 \%$ identity with c-Fos over the indicated conserved basic region. The positions of the leucines within the leucine zipper domain are indicated by asterisks $\left({ }^{*}\right)$. The DNA-binding and leucine zipper domains of TEF are functionally defined below (see Figs. 7 and 9). 
Figure 2. TEF mRNA is enriched in thyrotrophs on el4 and e18. $(A)$ Schematic diagrams of the midsagittal serial photomicrographic sections shown in $B-D$. The anatomically distinct regions (Simmons et al. 1990) of the el4 (left) and el6 (right) sections through the anterior pituitary gland contain thyrotrophs $(T)$, corticotrophs $(C)$, and presumed stem cells for these and other anterior pituitary cell types such as somatotrophs and lactotrophs $\left(\mathrm{S}_{\mathrm{SL}}\right)$. Also labeled are the intermediate lobe of the pituitary gland (IL), posterior lobe of the pituitary gland (PL), hypothalamus (HY), median eminence (ME), and third ventricle $\left(V_{3}\right)$. Arrow indicates the region of thyrotroph development. (B) UV photomicrographs of $10-\mu \mathrm{m}$-thick sections counterstained with bis-benzimide to show all cell nuclei (original magnification, $80 \times$ ). (C) Dark-field photomicrographs of the sections in $B$ showing autoradiographic analysis of in situ hybridization with a ${ }^{35} \mathrm{~S}$-labeled TEF antisense RNA probe. Increased silver grain density indicates the presence of TEF transcripts in the region of thyrotroph development on el4 and el6. No specific hybridization was detected with a ${ }^{35} \mathrm{~S}$ labeled TEF sense strand RNA probe. A low level of background hybridization was observed outside of the thyrotroph region with both the specific antisense probe and the control sense probe. A systematic microscopic examination of parasagittal whole body sections on e14 revealed no detectable specific hybridization outside of the pituitary gland (data not shown). (D) In situ hybridization of serial sections adjacent to those in $C$ with a ${ }^{35}$ S-labeled TSH $\beta$ antisense RNA probe showing the distribution of TSH $\beta$ mRNA transcripts on e14 and e16. The pattern of TSH $\beta$ expression corresponded precisely to the pattern of TEF gene expression.
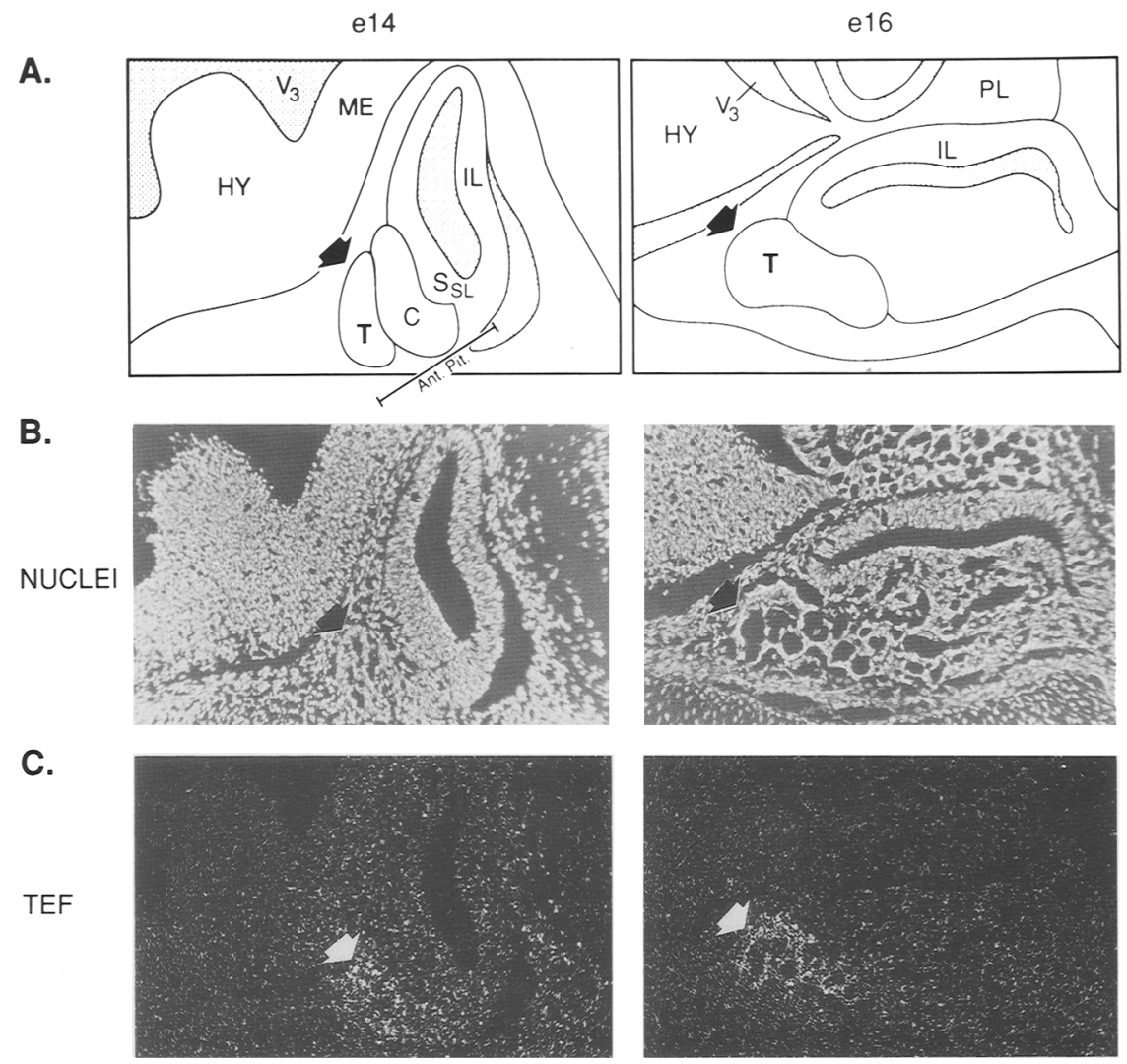

D.
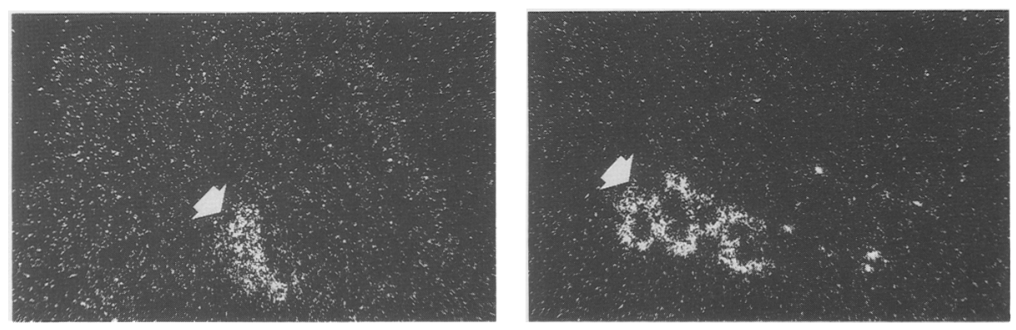

To examine the pattern of TEF gene expression after development was complete, both in situ and RNA blot analyses were performed. A TEF antisense RNA probe was used for in situ hybridization of a frontal brain section from an adult male rat. Strong hybridization signals were detected in the hippocampus, ventromedial nucleus of the hypothalamus, piriform cortex, and medial nucleus of the amygdala (Fig. 3A). RNA blot analyses showed the presence of $4.3-\mathrm{kb}$ TEF transcripts in the GC pituitary cell line as well as in brain, heart, and spleen of 3-week-old rats (Fig. 3B). Ribonuclease protection assays demonstrated the presence of TEF transcripts in lung, kidney, muscle, and liver as well as heart, spleen, and brain of 21-day-old rats (data not shown). These results show that although TEF transcripts exhibit a highly restricted distribution during embryogenesis, TEF tran- scripts appear in several tissues in the juvenile and adult rat.

\section{TEF can bind to specific elements within pituitary-specific gene promoters}

Because of the selective accumulation of TEF transcripts in developing thyrotrophs, we wanted to determine whether TEF could bind directly to specific nucleotide sequences within the mouse TSH $\beta$ thyrotroph-specific promoter (Gordon et al. 1988). As shown by a DNase I footprinting assay (Fig. 4A,B), bacterially expressed TEF protein was found to generate three independent footprints within the proximaI $1.2 \mathrm{~kb}$ of the TSH $\beta$ promoter $(1-82$ to -58$)$ box $1 ;(-209$ to -180$)$ box $2 ;(-534$ to $-517)$ box 3]. These data suggested the possibility that 


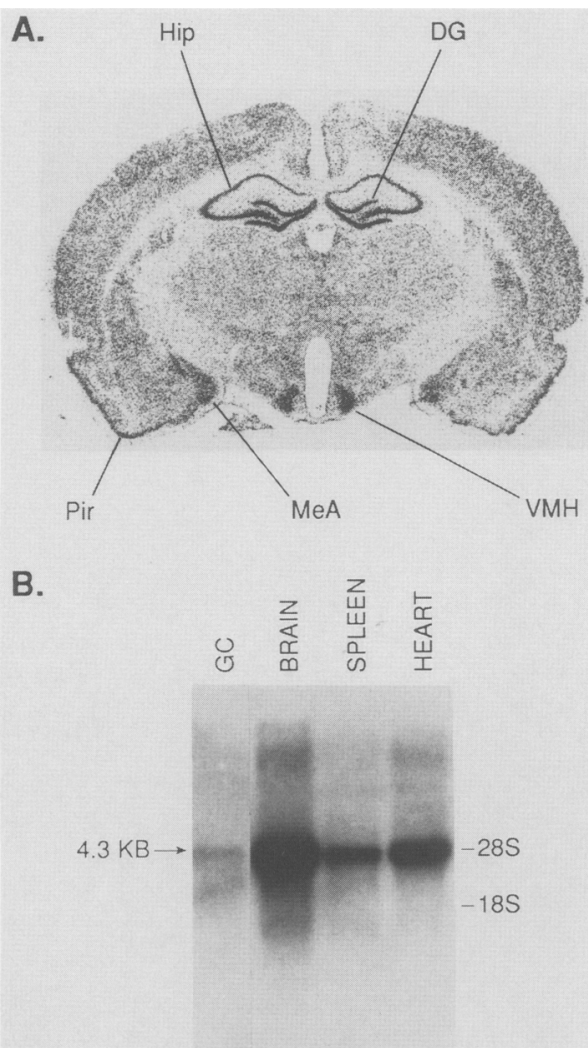

Figure 3. TEF gene expression following development. (A) A radiolabeled TEF-specific antisense RNA probe was used to detect the presence of TEF transcripts in frontal sections of an adult male rat brain. This $\mathrm{X}$-ray film autoradiograph shows the strongest positive hybridization signals for TEF mRNA. Shown are hippocampus (Hip) including the dentate gyrus (DG); ventromedial nucleus of the hypothalamus $(\mathrm{VMH})$; medial nucleus of the amygdala $(\mathrm{MeA})$; and piriform cortex $(\mathrm{Pir}) .(B)$ A radiolabeled TEF cDNA probe was used to detect the presence of TEF transcripts in poly $(\mathrm{A})$-selected RNA $(5 \mu \mathrm{g})$ isolated from a pituitary cell line $(\mathrm{GC})$ or from brain, heart, and spleen of 3-weekold rats. The migration of $18 \mathrm{~S}$ and $28 \mathrm{~S}$ RNA, and the size of the reactive species are indicated.

TEF could activate transcription by binding directly to the TSH $\beta$ promoter.

Because TEF transcripts were identified initially in the somatomammotroph cell line (GC), TEF binding to the rat prolactin and growth hormone promoters was also assessed. Only a single TEF footprint $(-66$ to -48$)$ could be detected within the proximal $422 \mathrm{bp}$ of the prolactin promoter (Fig. 4C). The nucleotide sequence contained within this footprint encompassed the sequence used to clone TEF. Although one of the Pit-1 footprints on the prolactin promoter overlapped with the TEF footprint (Fig. 4C), TEF and Pit-1 were not capable of co-occupying this site (data not shown). TEF was also shown to bind to a site $(-237$ to -220$)$ within the rat growth hormone promoter (Fig. 4D) at a region not absolutely required for pituitary-specific expression (Lira et al. 1988). Examination of these five footprints established a minimal TEF
DNA-binding consensus sequence of $5^{\prime}-\mathrm{T} / \mathrm{CA} / \mathrm{G} \mathrm{A} /$ G TT A T/C A/G-3'.

TEF can trans-activate a reporter gene under the transcriptional control of the TSH $\beta$ promoter

Because of the ability of TEF to bind to specific sites on the TSH $\beta$ promoter, we examined whether or not TEF could affect the expression of a gene under the transcriptional control of this promoter. To address this question, a cDNA fragment containing the coding sequence for wild-type TEF (amino acids 1-261) was inserted into a mammalian expression vector (pCMV1) (Ingraham et al. 1990) downstream of the cytomegalovirus (CMV) enhancer/promoter. The resulting TEF expression vector (pCMV/TEF) was cotransfected into African green monkey kidney (CV-1) cells with a reporter plasmid consisting of a firefly luciferase gene (deWet et al. 1987) under the transcriptional control of the murine TSH $\beta$ proximal promoter region -1228 to +8 (pTSH $\beta 1228-\mathrm{LUC})$. Because TEF transcripts were also found in the GC somatomammotroph cell line and because TEF can bind to the rat prolactin and growth hormone promoters, $\mathrm{pCMV} / \mathrm{TEF}$ was also cotransfected into CV-1 cells with reporter plasmids containing the firefly luciferase gene under the transcriptional control of either the rat prolactin proximal promoter (pPrl422-LUC), the rat growth hormone proximal promoter (pGH320-LUC) or the rat prolactin distal enhancer fused to a rat prolactin minimal promoter (pPrl DE-LUC).

As shown in Figure 5, cotransfection of TEF with pTSH 31228 -LUC produced a 200-fold increase in luciferase activity over the level obtained when the reporter plasmid was cotransfected with pCMV1. Cotransfection of $\mathrm{pCMV} / \mathrm{TEF}$ with pPrl422-LUC or pGH320LUC resulted in significant although lesser increases in luciferase activity (25- and 5-fold, respectively). No stimulation of luciferase activity was observed in cotransfection with pPrlDE-LUC.

In comparison, the transcriptional activator Pit-1 can stimulate luciferase activity $\sim 100$-fold in cotransfection experiments with pPrl422-LUC (Ingraham et al. 1988) but cannot stimulate luciferase activity in cotransfections with pTSH $\beta 1228-$ LUC (V.R. Albert and D.W. Drolet, unpubl.). It seems unlikely that TEF exerts significant transcriptional effects on the prolactin and growth hormone promoters in vivo for two reasons: (1) Pit-1 binds to the Prl-1P site with a higher affinity than does TEF; (2) cotransfection of TEF and Pit-1 does not significantly alter the transcriptional effects observed with Pit-1 alone (D.W. Drolet, unpubl.).

\section{A major TEF trans-activation domain is amino-terminal of the $T+D$ homology}

Several different motifs, including proline-rich and acidic-rich motifs, have been described as trans-activation domains (for review, see Ptashne 1988; Mitchell and Tiian 1989; Struhl 1989). To determine the region or regions of TEF responsible for trans-activation, portions of 

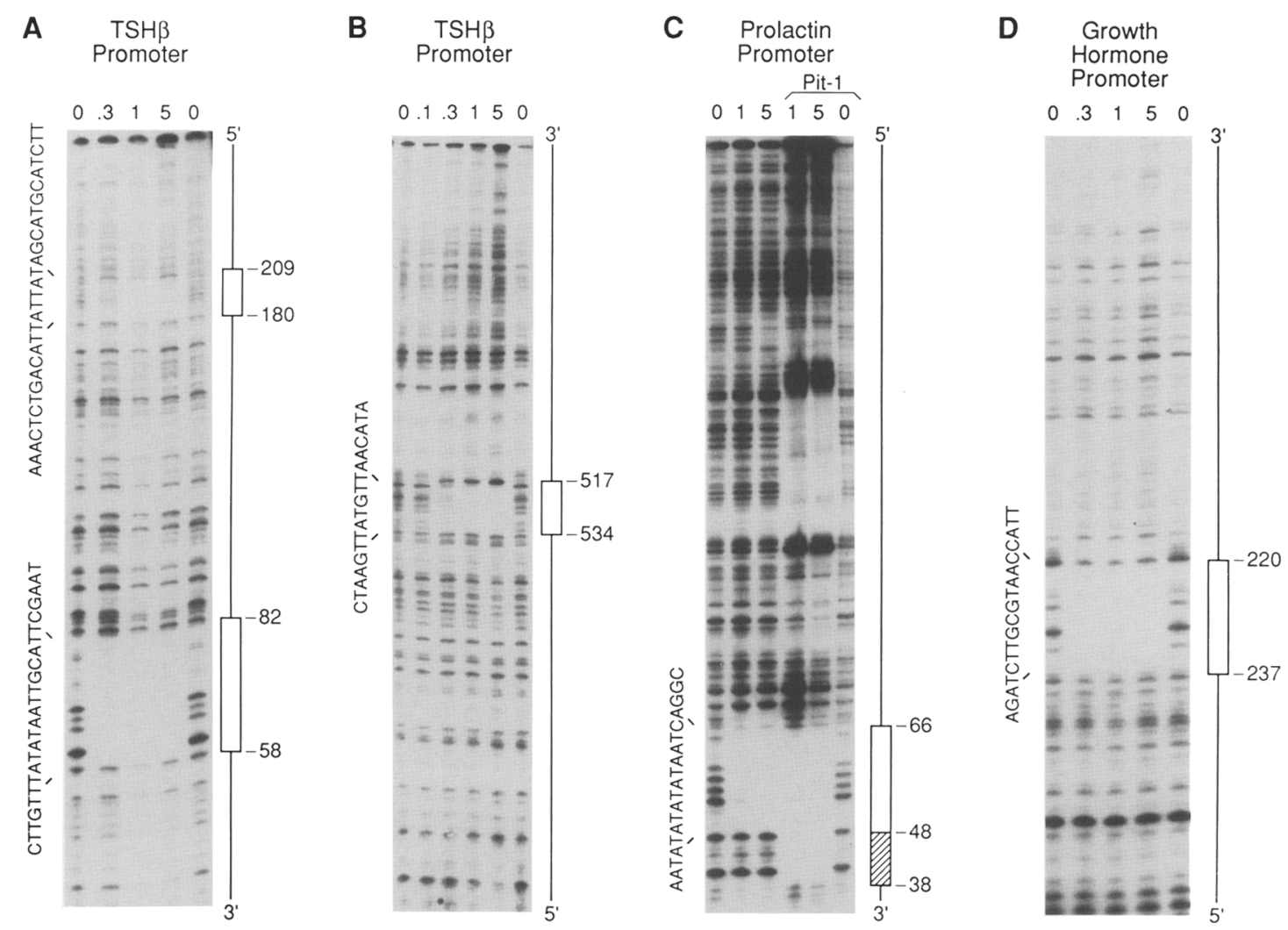

Figure 4. Site-specific binding of TEF to the TSH $\beta$, prolactin, and growth hormone promoters. DNase I footprinting assays were performed as described previously (Nelson et al. 1988) with bacterially expressed wild-type TEF and Pit-1 proteins. Promoter constructs were obtained by a PCR strategy as described in Materials and methods. The identities of the promoter fragments are indicated at top. Coordinates of each footprint and the sequence contained within the footprint are indicated at right and left, respectively. The relative amount of protein used in each assay is indicated at the top of each lane and, unless otherwise stated, represents an extract containing TEF. $(A)$ Mouse TSH $\beta$ promoter region $(-326$ to +18$)$ end-labeled at position -326 . $(B)$ Mouse TSH $\beta$ promoter region $(-662$ to -185$)$ end-labeled at position -185 . $(C)$ Rat prolactin promoter region $(-422$ to +3$)$ end-labeled at position +3 . Only the coordinates of TEF and Pit-1 footprints on the Prl-1P site are indicated. The extension of the observed Pit-1 footprint over that of the TEF footprint is indicated by the hatched box. $(D)$ Rat growth hormone promoter region $(-320$ to +1$)$ end-labeled at position -320 .

TEF were transferred to a heterologous DNA-binding domain provided by the amino-terminal 87 -amino-acid residues of bacterial LexA (Brent and Ptashne 1985). lexATEF fusion genes were cotransfected into CV-1 cells with a reporter plasmid ( $22 x L e x-L U C)$ consisting of a firefly luciferase reporter gene under the transcriptional control of two copies of the LexA DNA recognition element (Brent and Ptashne 1985). This assay eliminates any consideration of cooperativity between domains for transcriptional activity. The LexA-TEF fusion protein containing amino acids 7-123 of TEF stimulated reporter gene activity 15-fold (Fig. 6A). In contrast, LexA-TEF fusion proteins containing only the PAR region (amino acids 124-175), the basic region (amino acids 176-218), or the leucine zipper region (amino acids 219-255), failed to stimulate reporter gene activity. Thus, at least in this context, the unique PAR region did not subserve a transcriptional activation function. None of the LexA-TEF fusion proteins stimulated luciferase activity in cotransfections with a reporter construct bearing three copies of a palindromic thyroid hormone $\left(T_{3}\right)$ response element (Glass et al. 1988) in place of the LexA elements, con- firming the dependence on the LexA-binding elements for the transcriptional activity of LexA-TEF fusion constructs (data not shown).

To confirm the potential role of amino acids 7-123 of TEF in trans-activation, expression vectors coding for wild-type TEF or a TEF mutant lacking amino acids 7-123 (pCMV/ $\Delta \mathrm{N}_{7-12}$ ) were cotransfected individually into CV-1 cells with a reporter plasmid containing the firefly luciferase gene under the transcriptional control of three copies of a TEF recognition element. As shown in Figure 6B, deletion of residues 7-123 reduced TEFdependent trans-activation by $>75 \%$. Both TEF expression vectors failed to enhance the transcription of a promoter containing palindromic $T_{3}$ response elements in place of the TEF response elements, demonstrating the dependence on the TEF recognition element for the transcriptional activity of both constructs. Nuclear extracts obtained from CV-1 cells transiently transfected with either wild-type or mutant TEF expression vectors had comparable levels of TEF protein as determined by mobility-shift analyses (data not shown). Thus, both transfer and deletion analyses mapped a major trans-activa- 


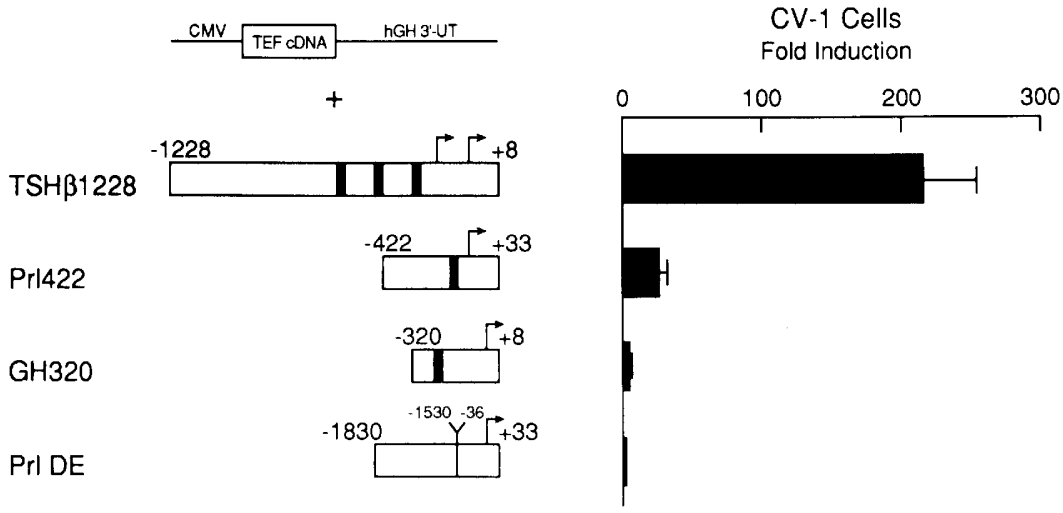

Figure 5. TEF trans-activation of pituitary-specific promoters in CV-1 cells. A 3.1-kb TEF restriction fragment containing the coding sequence for amino acids 1-261 of TEF was placed into the eukaryotic expression vector pCMV1 (see Materials and methods). The resulting pCMV/TEF construct was cotransfected into CV-1 cells along with a reporter plasmid consisting of either the mouse TSH $\beta$ promoter region $(-1228$ to +8 ; $\mathrm{TSH} \beta 1228)$; the rat prolactin promoter region) $(-422$ to +33 ; Prl422); the rat prolactin distal enhancer region $\mid-1830$ to -1530 ) fused to the rat prolactin promoter region $(-36$ to +33 ; Prl DE); or the rat growth hormone promoter region $1-320$ to +8 ; $\mathrm{GH} 320$ ) fused upstream of a firefly luciferase reporter gene (deWet et al. 1987). Results are reported as fold induction and represent the luciferase activity observed in cotransfection of a reporter plasmid with pCMV/TEF relative to the basal level of activity observed in cotransfections of a reporter plasmid with pCMV1. Average basal activity (light units/10 sec per $100 \mu \mathrm{g}$ of total protein) was as follows: (TSH 31228$)$ 155; (Pr1422) 1187; (GH320) 1197; (Prl DE) 1898. Results are the average of triplicate determinations (normalized to 100 $\mu \mathrm{g}$ of cell protein $) \pm$ S.E.M., as determined by the delta method. Similar results were obtained in four independent experiments.

tion domain to amino acids $7-123$ of TEF. If TEF should contain further amino-terminal coding information, this could modulate the activity of this trans-activating domain. The region of TEF, which conferred and transferred trans-activation, shares no significant homology to other known trans-activation domains, although it does contain regions rich in negatively charged amino acids.

\section{DNA-binding specificity of TEF can be altered by mutations in a cluster of basic amino acids}

The presence of the PAR region made it necessary to define the regions of TEF necessary for its DNA-binding activity. Therefore, a series of bacterially expressed TEF mutants (Fig. 7A) was tested for DNA-binding activity with a mobility-shift assay. Wild-type TEF, as well as a TEF mutant $\left(\Delta \mathrm{N}+\Delta \mathrm{PAR}_{1-175}\right)$ containing only the basic and leucine zipper regions, was capable of binding to the TEF growth hormone promoter recognition element (Fig. 7A,B). Deletion of either the leucine zipper motif $\left(\Delta\right.$ Zipper $\left._{219-255}\right)$ or the basic region $\left(\Delta\right.$ Basic $\left._{176-218}\right)$ eliminated DNA binding completely. The efficient expression of these latter two mutants was confirmed by SDSPAGE (Laemmli 1970). Substitution of valines for the first two leucines of the leucine zipper motif [L/226; 233) $\rightarrow$ V] diminished DNA binding (Fig. 7) as did similar substitutions in other bZIP family members (Kouzarides and Ziff 1988; Gentz et al. 1989; Landschulz et al. 1989; Turner and Tiian 1989). Deletion of the PAR region $\left(\triangle \mathrm{PAR}_{124-175}\right)$ did not eliminate binding to the growth hormone recognition element (Fig. 7). Apparently, the $\triangle$ PAR mutant was susceptible to proteolysis of the amino terminus resulting in additional complexes with faster mobilities than the intact mutant in both SDSpolyacrylamide gels and the mobility-shift assay. These data indicated that only the basic and leucine zipper domains were required for TEF DNA binding as has been reported for other members of the bZIP gene family (Kouzarides and Ziff 1988; Gentz et al. 1989; Landschulz et al. 1989; Turner and Tjian 1989).
A cluster of basic amino acids within the DNA-binding domain of TEF (residues 178-182) is conserved between TEF and DBP but not between TEF and the other members of the bZIP gene family. In TEF, this basic amino acid cluster consists of the sequence KKAKK, whereas in DBP, it consists of the sequence KKARK. This TEF/DBP-specific basic cluster is amino-terminal to the basic region conserved among the entire bZIP family (for review, see Busch and Sassone-Corsi 1990) (Fig. 1B). Mutations of basic residues within the conserved bZIP basic region have been shown previously to interfere with DNA binding (Kouzarides and Ziff 1988; Gentz et al. 1989; Landschulz et al. 1989; Turner and Tjian 1989).

To evaluate the role of the TEF/DBP-specific basic cluster in the DNA-binding activity of TEF, pairs of lysines were mutated to alanines by site-directed mutagenesis resulting in the mutants $\mathrm{K}(178 ; 179) \rightarrow \mathrm{A}$ and $\mathrm{K}(181 ; 182) \rightarrow \mathrm{A}($ Fig. 8A). The relative DNA-binding affinities of bacterially expressed wild-type TEF and the TEF-binding site mutants for both the prolactin and growth hormone TEF recognition elements were evaluated by competition analyses with the mobility-shift assay (Fig. 8B-D). The prolactin and growth hormone TEF recognition elements contain different nucleotides at three locations within the consensus DNA recognition sequence for TEF. Although the affinity of wild-type and mutant TEF proteins for the growth hormone DNA recognition element was virtually identical, the affinity of the mutants for the prolactin recognition element was decreased by $>30$-fold as compared to wild-type TEF. Because the relative affinities of both mutant proteins for these two elements were different from wild-type TEF, the TEF/DBP-specific basic cluster appears to affect the specificity of DNA binding.

Two experimentally distinguishable explanations for this result can be envisaged. The basic cluster might participate directly in TEF-DNA interactions that are important for the recognition of the prolactin element but are negligible for the recognition of the growth hormone element. In this case, mutant TEF-DNA contacts are 
Figure 6. Mapping of a major trans-activating domain of TEF. (A) The ability of various TEF regions to transfer trans-activation function to a transcriptionally inactive LexA DNA-binding-domain was assessed by transient cotransfection analysis. TEF cDNA fragments coding for the TEF amino acids $7-123$, the PAR region (amino acids 124-175), the basic domain (amino acids 176-218), or the leucine zipper domain (amino acids 219-255) were individually fused in-frame to amino acid residues 1-87 of LexA and cloned into pCMV1 (see Materials and methods|. LexA and LexATEF expression plasmids were cotransfected individually with a reporter plasmid $(2 \times$ Lex $)$ containing a firefly luciferase gene under the transcriptional control of two copies of the LexA-binding site inserted upstream of a prolactin minimal promoter region ( -36 to +33 ) (Ingraham et al. 1988). The fold inductions represent luciferase activity from a cotransfection with a LexATEF fusion construct divided by a cotransfection with LexA alone. Results were standardized to $100 \mu \mathrm{g}$ of cell protein and are reported as the mean induction $(n=4) \pm$ S.E.M. (determined by the delta method). Similar results were obtained in three independent experiments. None of the constructions were able to direct transcription from a reporter construct bearing three copies of a $T_{3}$ response element in place of the LexA-binding elements (data not shown). (B) Eukaryotic expression vectors containing wild-type TEF (WT) and an amino-terminal TEF deletion mutant $\left(\Delta \mathrm{N}_{7-123}\right)$ were constructed as described in Materials and methods. The transcriptional activity of TEF $\Delta \mathrm{N}_{7-123}$ was compared to wild-type TEF by cotransfection with a reporter plasmid $(3 \times \operatorname{Prl}-1 \mathrm{P})$ consisting of a firefly luciferase gene under the transcriptional control of three copies of the Prl-1P element placed in front of a minimal prolactin promoter fragment $(-36$ to +33$)$. The light units obtained from wild-type TEF were averaged $(n=4)$ and set at $100 \%$. Results are presented as a percentage of this value \pm S.E.M. per $100 \mu \mathrm{g}$ of cell protein. Similar results were obtained from three independent experiments. Both expression constructs failed to direct transcription from a reporter construct containing three $T_{3}$ response elements in place of the Prl-1P elements (data not shown).

likely to be different from wild-type TEF-DNA contacts on the prolactin element, but identical on the growth hormone element. Alternatively, mutations in this basic cluster might affect the conformation of the DNA-binding domain in general, rather than participate in TEFDNA interactions directly. In this case, mutant TEFDNA contacts could be different from wild-type TEF on both elements. Methylation interference experiments were performed to distinguish between these two possibilities. As indicated by an increased sensitivity to specific methylated guanosine residues, the mutants contacted both the growth hormone and prolactin recognition elements differently from wild-type TEF (Fig. 8E). These data suggest that because of its effect on the structure of the DNA-binding domain, the conservation of this basic cluster is important for maintaining the proper DNA-binding specificity of TEF.

The leucine zipper motif mediates the formation of TEF homodimers

Leucine zipper domains are coiled-coil structures that mediate dimerization and that have been shown to be necessary for efficient DNA binding of bZIP proteins (Kouzarides and Ziff 1988; Gentz et al. 1989; Landschulz et al. 1989; Turner and Tjian 1989|. To determine whether TEF also bound to DNA as a dimer, mixing experiments were performed by a modification of the method of Hope and Struhl (1987). Wild-type TEF, as well as a truncated TEF protein $\left(\triangle \mathrm{N}+\triangle \mathrm{PAR}_{176-261}\right)$, was produced by in vitro transcription and translation, and assayed for DNA binding by the mobility-shift assay (Fig. 9A). As expected, when assayed individually, both TEF proteins formed complexes that exhibited a distinct mobility. When these two proteins were cotranslated, a third complex, intermediate in mobility to the original two, was observed in the assay (Fig. 9A, lane 4). These data are consistent with the assumption that TEF binds to a DNA recognition element as a leucine zipper-mediated dimer.

We then wanted to determine whether the leucine zipper motif could direct the formation of dimers in the absence of DNA. Wild-type TEF and the same series of bacterially expressed TEF mutants as shown in Figure 
A

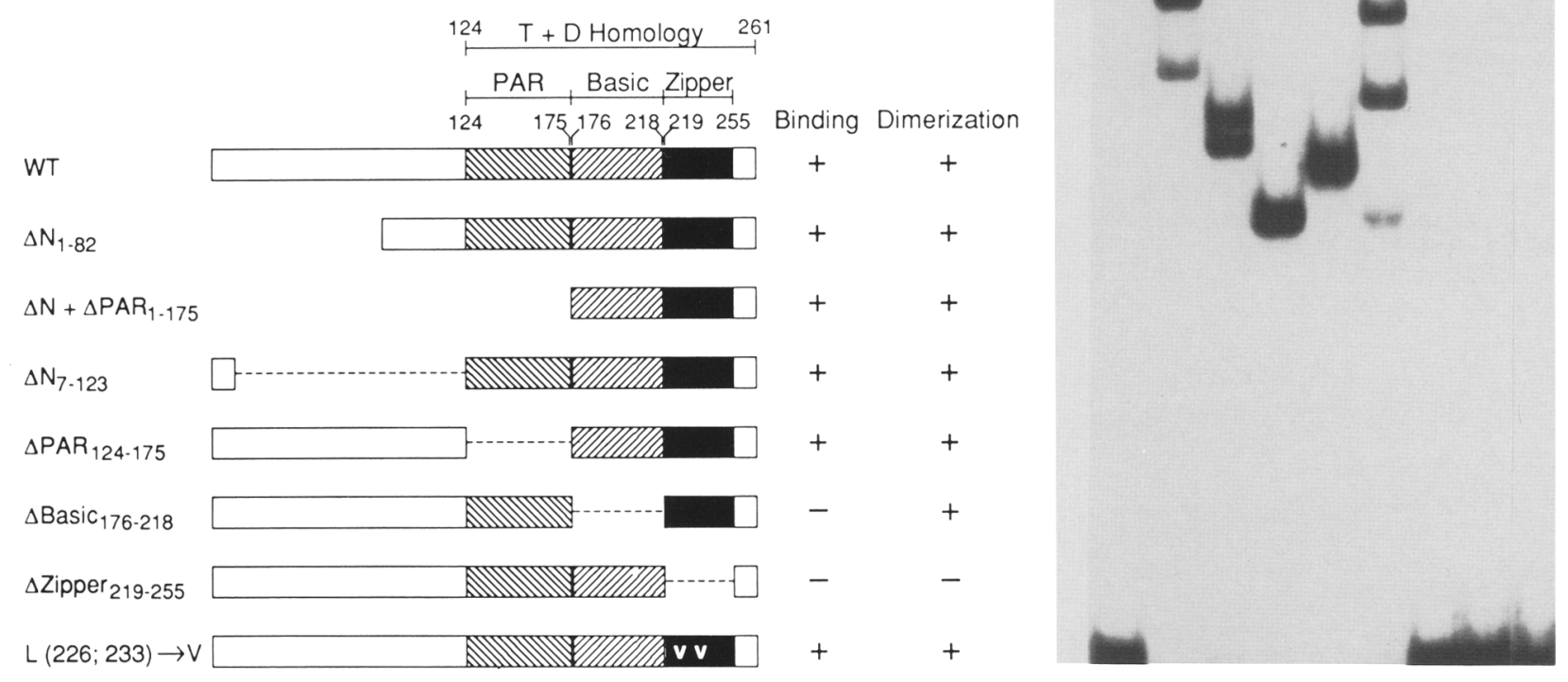

Figure 7. DNA-binding analyses of wild-type and mutant TEF proteins. (A) Schematic representation of wild-type (WT) and mutant TEF proteins constructed and expressed in bacteria as described in Materials and methods. The region of homology between TEF and $\mathrm{DBP}$ ( $\mathrm{T}+\mathrm{D}$ homology) is shown at top. The PAR, basic, and leucine zipper regions are indicated at the top and are shown schematically by hatched and solid regions. The binding and dimerization activity of wild-type TEF and the TEF mutants are summarized by + , indicating the ability to bind DNA or form dimers in solution, or - , indicating no detectable DNA binding or dimerization activity. (B) Mobility-shift analysis of bacterially expressed wild-type and mutant TEF proteins with a radiolabeled double-stranded oligonucleotide, 5'-CTGAGATCTTGCGTAACCATT-3', corresponding to coordinates -240 to -220 in the rat growth hormone promoter. Equivalent amounts of protein, as judged by immunoblot analysis, were used. The deletion mutant $\triangle \mathrm{PAR}_{124-175}$ shows multiple complexes due to proteolysis of its amino terminus.

7A were tested for their ability to form covalently linked dimers after exposure to glutaraldehyde as a chemical cross-linklng agent. After incubating TEF proteins with glutaraldehyde, monomers were separated from covalently cross-linked species by SDS-PAGE (Laemmli 1970). TEF-containing complexes were subsequently detected by immunoblot analysis with a rabbit TEF antiserum directed against wild-type TEF. Wild-type TEF monomers have a mobility that is slower than predicted in this assay, perhaps due to the high proline content of the protein. As shown in Figure 9B, covalently linked dimers were detected for wild-type TEF and for all TEF mutants that contained the leucine zipper motif. Conversely, no covalently linked dimers could be detected with the mutant that only lacked the leucine zipper motif $\left(\Delta\right.$ Zipper $\left._{219-255}\right)$. Replacement of two leucines of the leucine zipper domain with valine $[L(226 ; 233) \rightarrow \mathrm{V}]$ diminished the dlmerization activity of TEF as has been shown for other members of the bZIP gene family (Gentz et al. 1989; Landschulz et al. 1989; Turner and Tjian 1989|. The low concentrations of glutaraldehyde used $(0.01 \%)$, and the absence of any cross-linked product other than dimers, indicate that this assay measured a stable association of TEF subunits in a dimeric complex. These data indicate that only the leucine zipper domain of TEF is necessary to mediate the formation of homodimers.

\section{TEF and DBP can form heterodimers}

Because of the extensive homology between TEF and DBP and the presence of both TEF and DBP transcripts in several adult tissues including liver, heart, and brain, as well as the GC cell line (this paper and Mueller et al. 1990), we investigated the possibility that these two proteins could form a heterodimer. To address this question, a truncated form of DBP, containing the putative DNAbinding and dimerization domains (residues 241-325), was expressed by in vitro transcription and translation. As determined by a mobility-shift assay, DBP was capable of binding independently to the TEF growth hormone recognition element (Fig. 9C, lane 2). When wild-type TEF and DBP were cotranslated and subjected to the same binding analysis, a complex with a mobility intermediate to the TEF and DBP complexes was observed 
Drolet et al.

Figure 8. A cluster of basic amino acids in the DNA-binding domain is important for binding site specificity. (A) Schematic representation of wildtype (WT) TEF and the TEF-binding domain mutants $[\mathrm{K}(178 ; 179) \rightarrow \mathrm{A}$ and $\mathrm{K}(181-182) \rightarrow \mathrm{A}]$, which contain different substitutions of pairs of alanine for Iysine residues within the DNA-binding domain. $(B)$ An example of the method used to obtain the competition data shown in $C$ and $D$. Shown are mobility shifts of wild-type TEF bound to a radiolabeled oligonucleotide containing the TEF growth hormone recognition site (see Fig. 7) in the presence of increasing concentrations (molar $\times 10^{-9}$ ) of unlabeled oligonucleotide as indicated at the top of each lane. Bound and free DNAs in each lane were measured by a computer-controlled imaging system that directly quantitates radiation (AMBIS). $(C)$ Competition curves for wild-type TEF and the DNA-binding domain mutant TEF proteins. Shown are the effects of increasing concentrations of the growth hormone recognition element on TEF binding to an identical but radiolabeled element. Molar concentrations are as indicated. $(D)$ Competition as in $C$, except the unlabeled double-stranded competitor oligonucleotide consisted of the Prl-1P TEF-binding element containing the sequence 5'-CCTGATTATATATATATTCATGAA- ${ }^{\prime}$, corresponding to the coordinates -65 to -42 of the rat prolactin gene (Nelson et al. 1988). (E) Methylation interference analyses of the binding of wild-type TEF and the TEF DNAbinding mutants to the growth hormone (left and middle) or the prolactin (right) TEF DNA recognition elements. Major groove contacts within the TEF consensus sequence are indicated by an asterisk $\left({ }^{*}\right)$.

(Fig. 9C, lane 4). This result is consistent with the formation of a TEF-DBP heterodimer.

Because DBP and C/EBP have overlapping DNA-binding specificities (Friedman et al. 1989; Mueller et al. 1990 ), we determined whether or not C/EBP could also bind to the TEF growth hormone-binding site. As shown

E.
A.

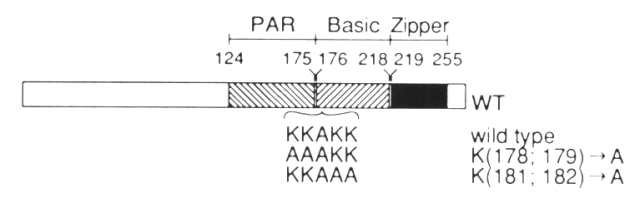

B. $0 \hat{0} \stackrel{m}{-} \ddot{\sim} \stackrel{m}{m}=\bar{N}$

C.

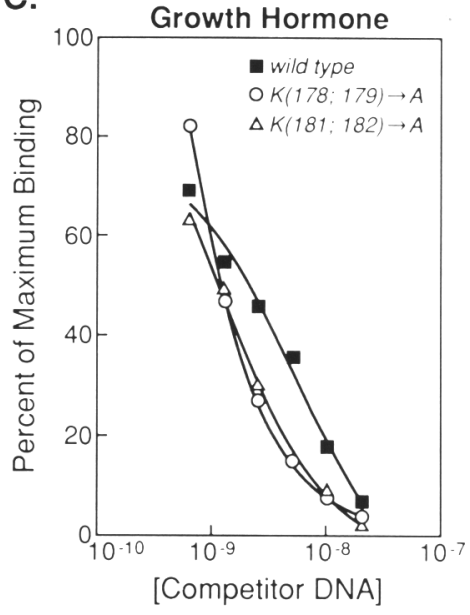

D.

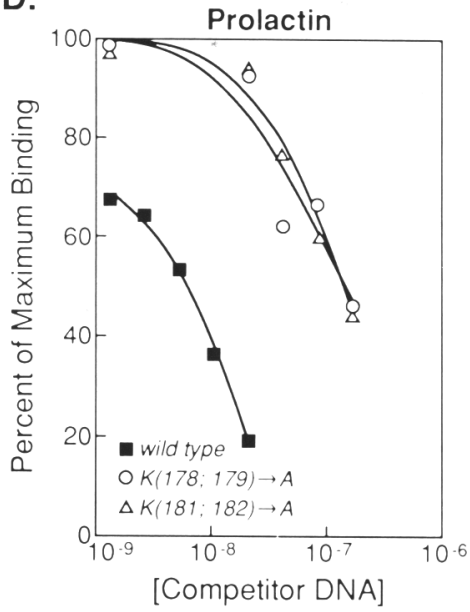

GH Sense

GH Antisense

Prolactin Sense
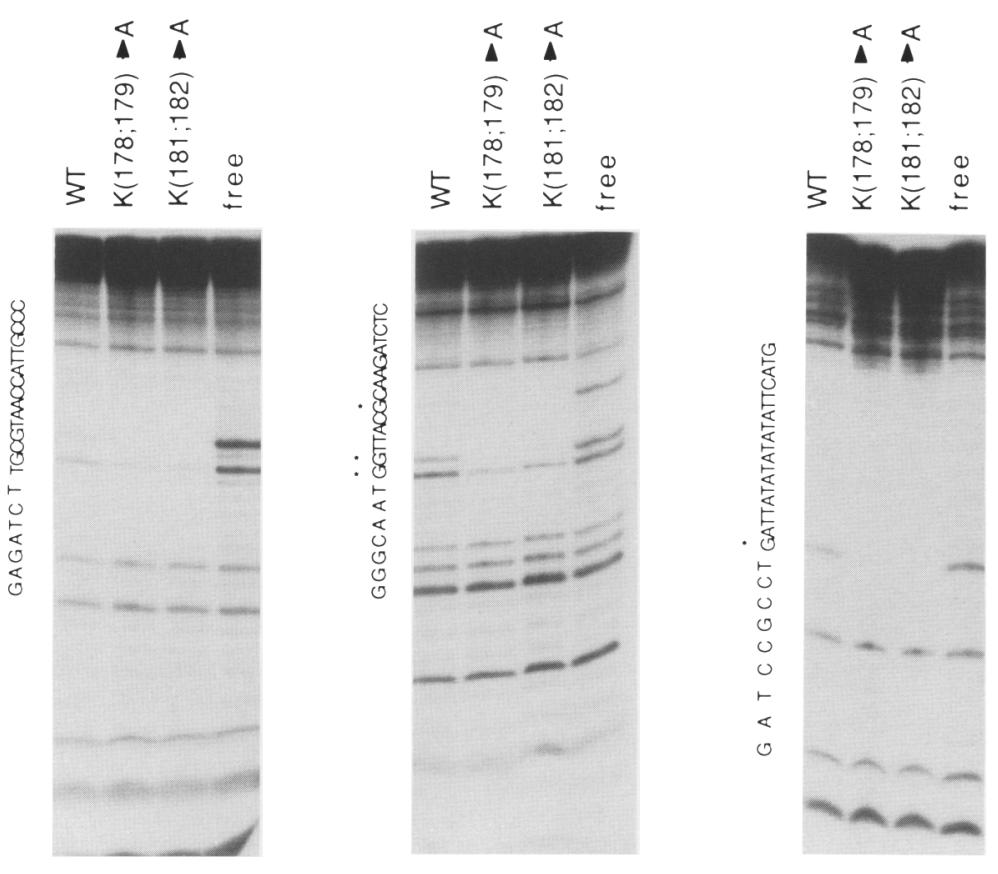

by the mobility-shift assay, in vitro-translated rat C/EBP was also able to bind to the TEF growth hormone element (Fig. 9C, lane 6). However, in contrast to the ability of TEF and DBP to form heterodimers capable of binding to this element, no heterodimer formation could be detected when C/EBP was cotranslated with either TEF or 
A.

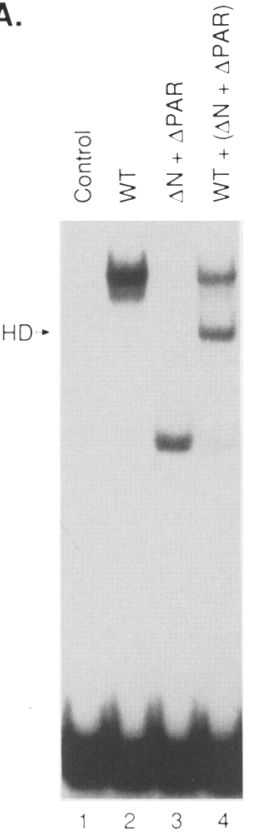

C.

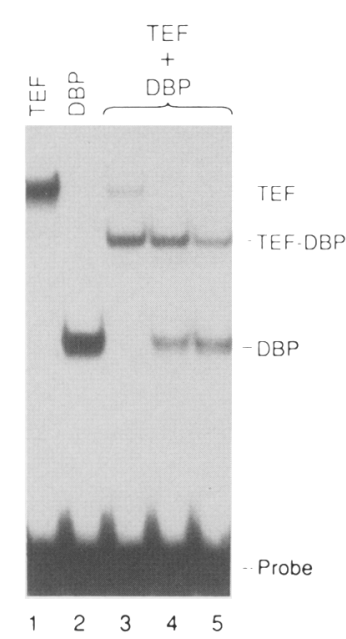

B.

D.
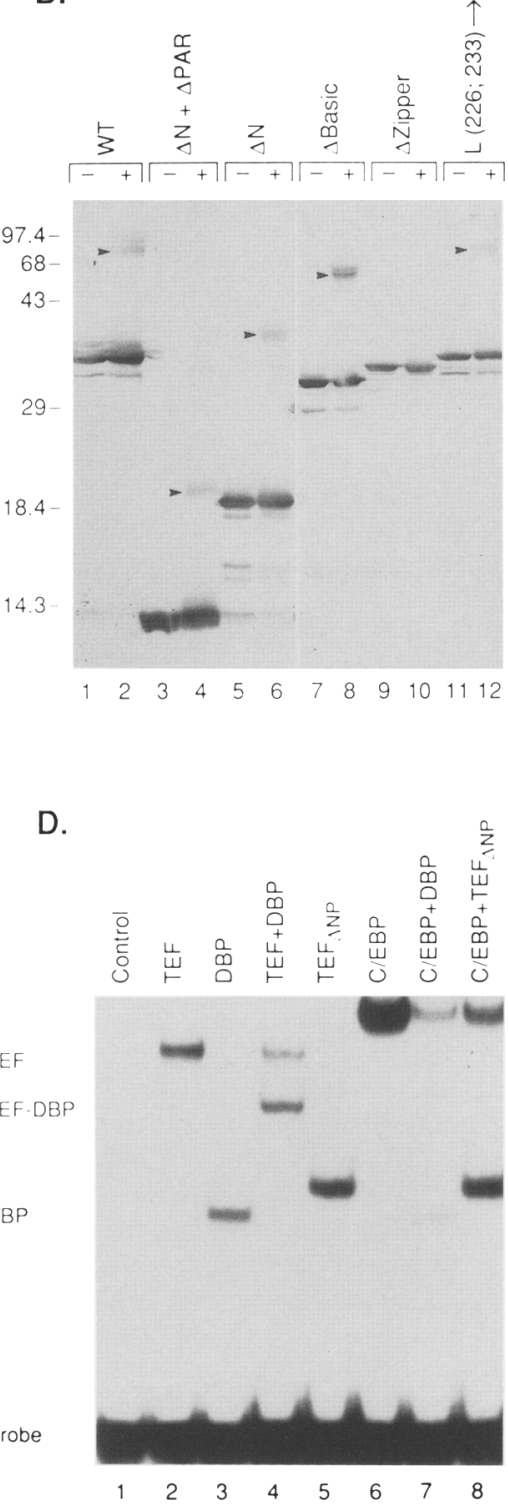

DBP (Fig; 9D, lanes 7,8). These results suggest that although members of two different classes of bZIP transcription factors may bind to the same cis-active element, they do not form heterodimers on that element.

\section{Discussion}

\section{A new class of bZIP proteins}

In this report we present evidence for the existence of a new class, the TEF-DBP class, of bZIP transcriptional regulatory proteins. Both the homology between TEF and DBP and the ability of these proteins to form heterodimers support the separate classification of TEF and DBP. The homology between TEF and DBP ( T + D homology) includes a region (PAR) that is unique to these two members of the bZIP gene family. Structure-function studies presented here verify the role of the conserved leucine zipper domain in mediating dimerization

Figure 9. A TEF dimer or a TEF-DBP complex binds to the same DNA recognition element. (A) Mobility-shift analysis of in vitro-translated wild-type TEF (WT), a TEF deletion mutant containing only the DNA-binding and leucine zipper domains $\left(\Delta \mathrm{N}+\Delta \mathrm{PAR}_{1-175}\right)$, or wild-type TEF cotranslated with $\Delta \mathrm{N}+\Delta \mathrm{PAR}_{1-175}$ (lane 4). The position of a complex dependent on the cotranslation of wild-type TEF and $\Delta N+\Delta \mathrm{PAR}_{1-175}$ and consistent with a heterodimer is indicated by HD. (B) Glutaraldehyde cross-linking of bacterially expressed wild-type and mutant TEF proteins. Bacterially expressed proteins were left untreated $(-)$ or treated $(+)$ for $3 \mathrm{~min}$ at room temperature with $0.01 \%$ glutaraldehyde. Samples were then resolved by SDSPAGE, and TEF proteins were detected by an immunoblot assay with a rabbit antiserum directed against wild-type TEF. The positions of molecular mass standards (in kilodaltons) are shown at left. Arrowheads indicate the position of cross-linked dimers. $(C)$ Interaction of TEF and DBP on a TEF growth hormone recognition element. Wild-type TEF (lane 1) or a truncated DBP (lane 2) were translated independently or cotranslated (lanes 3-5) in vitro and analyzed for DNA-binding activity by a mobility-shift assay. The position of TEF, DBP, and the TEF-DBP heterodimer are indicated at right. Lanes 4 and 5 contain two and three times, respectively, the input of DBP RNA in the translation reaction as compared to lane $4 .(D)$ TEF and DBP do not interact with C/EBP on the TEF growth hormone recognition element. The rat bZIP transcription factor C/EBP was translated in vitro and analyzed for the ability to bind to the TEF growth hormone element (lane 6). C/EBP was also cotranslated with a DBP deletion mutant containing only the basic and leucine zipper domains (lane 7) or the TEF $\triangle N+$ PAR deletion mutant $\left(\mathrm{TEF}_{\triangle \mathrm{NP}} ;\right.$ lane 8$)$. In contrast to the ability of TEF and DBP to form a heterodimer capable of binding to the TEF growth hormone recognition element (lane 4), no heterodimer formation was observed between C/EBP and TEF or C/EBP and DBP.

within this class of bZIP transcription factors. In addition, mutational analysis of the DNA-binding domain of TEF has identified a functional role for a basic aminoacid-rich cluster, amino-terminal to the consensus bZIP DNA-binding domain (for review, see Johnson and McKnight 1989; Busch and Sassone-Corsi 1990). This cluster, required for high-affinity binding to a subset of DNA recognition elements, is conserved between TEF and DBP but not among the other members of the bZIP family. We suggest that this region be considered a part of the DNAbinding domain of the TEF-DBP class of bZIP proteins.

The coexpression of proteins that could form heterodimers with TEF, such as DBP, or that could bind to the same or overlapping DNA-binding element, such as $D B P$ and $C / E B P$, is intriguing. Both DBP and C/EBP have been implicated as developmental transcriptional regulators. For example, C/EBP and DBP are enriched late in liver development, and their expression has been corre- 
lated with high levels of expression of the albumin gene (Birkenmeier et al. 1989; Friedman et al. 1989; Mueller et al. 1990). The appearance of C/EBP transcripts in the GC cell line (J.M. Mathis and M. Wegner, unpubl.), as well as TEF and DBP transcripts, illustrates the potential for complex interactions among these or other members of the C/EBP and TEF-DBP classes of bZIP proteins. Transcripts for TEF, DBP, and C/EBP exhibit a widespread and overlapping distribution in the adult /this paper; Birkenmeier et al. 1989; Mueller et al. 1990), consistent with the potential for differential control of gene transcription by the regulated expression of these three proteins.

\section{TEF and pituitary development}

The identification and initial characterization of TEF has intriguing implications with regard to the molecular mechanisms by which five phenotypically distinct cell types emerge from what appears initially to be a single homogenous layer of somatic ectoderm forming Rathke's pouch. Each mature cell type arises in a precise temporal and spatial pattern in the developing rat anterior pituitary gland; thyrotrophs and corticotrophs are the first two cell types to emerge (Simmons et al. 1990). The activation of the gene encoding TSH $\beta$ on e14, within the cells at the rostral tip of the anterior pituitary gland, defines the birth of the thyrotroph cell type (Simmons et al. 1990). Understanding of the molecular mechanisms responsible for the initial activation and maintenance of TSH $\beta$ gene expression has been impeded by the lack of a convenient model system (for review, see Schupnik et al. 1989|. However, the analysis of genetic dwarf mice by Li et al. (1990) has implicated the pituitary-specific transcription factor Pit-1 (Bodner et al. 1988; Ingraham et al. 1988) in the maintenance of the thyrotroph phenotype even though Pit- 1 is expressed in the pituitary after the initiation of TSH $\beta$ expression (Simmons et al. 1990). In addition, several thyrotroph-specific footprints within the TSH $\beta$ promoter have been observed by using nuclear extracts from cells obtained from the thyrotroph TtT-97 transplantable tumor, which expresses both the $\alpha$-subunit and $\beta$-subunit of TSH (Wood et al. 1990).

In this paper we have shown that TEF transcripts are expressed selectively in the rostral portion of the rat anterior pituitary gland in the region in which thyrotroph development occurs. The temporal and spatial pattern of TEF gene expression within the embryo is identical to the pattern of TSH $\beta$ gene activation (Fig. 2). TEF transcripts remain restricted to the thyrotroph region on e16, a time by which all five anterior pituitary cell types has been established. Coupled with this observation, TEF can bind to three specific elements in the mouse TSH $\beta$ promoter and is a potent activator of this promoter. Because there may be instances of dissociation between the appearance of transcripts and the encoded protein, it will be of importance to establish the presence of TEF protein once monospecific antibody becomes available. Two TEF recognition elements within the TSH $\beta$ promoter $(-82$ to -58 , box- $1 ;-209$ to -186 , box-2) are conserved between mouse and rat (Carr et al. 1987; Gordon et al. 1988), but further sequence information is needed to de- termine whether the rat TSH $\beta$ promoter contains TEF box-3 $(-534$ to -517$)$. TEF box-1 overlaps with the more upstream of the two TATA boxes found in both the rat and mouse TSH $\beta$ promoters. The TEF box-1 footprint also coincides with one of the TtT-97-specific footprints $(-83$ to -63$)$ identified by Wood et al. (1990). On the basis of these observations, it is tempting to speculate that a member of a new class of bZIP transcription factors, TEF, functioning alone or in concert with other factors, acts in establishing one cell phenotype within the developing rat anterior pituitary gland. The observation that TEF does not exhibit a highly restricted pattern of expression in the mature organism may indicate that TEF exerts functions during development that are distinct from those in the mature organism, as has been suggested for other transcription factors (Akam 1987).

\section{Materials and methods \\ Cloning and sequencing of TEF CDNA}

Expression libraries containing cDNA derived from estrogentreated rat pituitary or the rat pituitary cell line (GC; Ingraham et al. 1988) were screened with a radiolabeled, multimerized oligonucleotide (Singh et al. 1988, Vinson et al. 1988), containing the sequence $5^{\prime}$-CCTGATTATATATATATTCATGAA-3' corresponding to the coordinates -65 to -42 of the rat prolactin gene (Nelson et al. 1986). Approximately $1 \times 10^{6}$ plaques were screened from each library, resulting in the isolation of a single bacteriophage plaque, from the GC library, that produced a fusion protein capable of binding the oligonucleotide. Two cDNA restriction fragments $(3.1$ and $0.9 \mathrm{~kb})$ from this recombinant isolate were subcloned separately into the unique EcoRI site of $\mathrm{pBKSII}^{-}$(Stratagene) creating the plasmids pBKS-TEF 3.1 and pBKS-TEF 0.9. Both strands of the cDNA inserts were sequenced by the chain-termination method (Sanger et al. 1977) by using double-stranded DNA template, synthetic oligonucleotide primers, and T7 DNA polymerase (Sequenase; U.S. Biochemical). To isolate independent cDNA clones, the estrogentreated rat pituitary library was screened by hybridization (Maniatis et al. 1982) with a 900-bp TEF cDNA EcoRI fragment radiolabeled by the method of Feinberg and Vogelstein (1983). Nine positive clones were obtained at a frequency of 1 in 40,000. Coding portions of four independent clones, the largest of which was $3.8 \mathrm{~kb}$, were sequenced and, in all cases, confirmed the nucleotide sequence of the original isolate.

\section{Polymerase chain reaction}

DNA fragments were obtained by amplification of specific cDNA sequences by using the polymerase chain reaction (PCR) with Taq DNA polymerase (Perkin-Elmer/Cetus) and synthetic oligonucleotides according to manufacturer's instructions. Amplification of DBP cDNA fragments was performed with DBPspecific oligonucleotide primers corresponding to nucleotide positions 1081-1112 and 1462-1492 (Mueller et al. 1990). Identical clones were obtained from cDNA derived from rat brain, rat heart, or the rat GC pituitary cell line. Although these three clones differed from the reported liver DBP (Mueller et al. 1990) by the addition of a single nucleotide downstream of the basic region, it is now apparent that all four clones share an identical sequence (U. Schibler, pers. comm.). The predicted amino acid sequence is shown in Figure 1B.

Plasmid construction and mutagenesis

A TEF bacterial expression vector (pET3a-TEF) was obtained by 
converting the nucleotide sequence encompassing the first inframe methionine of TEF into an NdeI site by a PCR strategy with pBKS-TEF3.1 as template. The NdeI-KpnI portion of the amplified DNA, containing the entire TEF-coding sequence, was subcloned into a modified pET3a bacterial expression vector that contains a unique NdeI site encompassing the translation start codon (Studier and Moffat 1986). TEF mutants that have an internal translational start site were engineered by a similar strategy. Introduction of point mutations or BstEII restriction sites at the boundaries of all internal deletion mutants was performed by the procedure of Kunkel (1985), with singlestranded DNA template from the pET3a-TEF or the pBKS-TEF3.1 vectors. After the introduction of unique BstEII sites, the fragment to be deleted was removed by BstEII digestion and the TEF deletion mutant was obtained by ligation of the remaining ends. The deleted fragments were recovered and subcloned individually into a unique BstEII site of the pLexA mammalian expression plasmid (Ingraham et al. 1990) to create the LexATEF fusion constructs. The mammalian expression plasmid pCMV/TEF was obtained by subcloning a ClaI-XbaI fragment from pBKS-TEF-3.1 into the mammalian expression vector pCMVl (Ingraham et al. 1990). The TEF amino-terminal deletion mutant pCMV-TEF- $\triangle \mathrm{N}$ was obtained in an identical manner after the amino-terminal deletion was obtained (see above). Amplified DBP cDNA, containing coding information for the DNA-binding and leucine zipper domains, was cloned by bluntend ligation into the unique SmaI site of $\mathrm{pBKSII}^{-}$creating the plasmid $\mathrm{pBKS}-\mathrm{DBP}_{\Delta \mathrm{NP}}$. All constructions were analyzed by restriction analysis and nucleotide sequencing.

\section{RNA analyses}

The 3.1-kb EcoRI restriction fragment from pBKS-TEF-3.1, containing the entire coding and most of the $3^{\prime}$-untranslated region, was used as a template for the generation of a radiolabeled probe as described previously (Feinberg and Vogelstein 1983). Poly(A)selected RNA, from a series of rat tissues and the GC pituitary cell line, was size-fractionated under denaturing conditions using formaldehyde-1.2\% agarose gels, transferred to nitrocellulose, and hybridized for $12 \mathrm{hr}$ as reported previously (Chirgwin et al. 1979; Maniatis et al. 1982). Blots were washed in $0.5 \times$ SSC at $60^{\circ} \mathrm{C}$ for $15 \mathrm{~min}$.

\section{Ontogenetic analyses}

Timed-pregnant Sprague-Dawley rats were purchased from Zivic-Miller (Zelienople; Pennsylvania); time of insemination (confirmed by vaginal plug) was at midnight and was considered the beginning of embryonic day $0(\mathrm{e} 0)$. An appropriate number of days later, animals were perfused or fixed by immersion in $4 \%$ paraformaldehyde and the tissues were processed as described previously (Simmons et al. 1900). In situ hybridizations were performed by using sense and antisense ${ }^{35} S$-labeled RNA probes transcribed from linearized DNA templates with Riboprobe Gemini kits (Promega Biotech; Madison, WI) and ${ }^{35}$ S-labeled UTP (1000-1500 Ci/mM; New England Nuclear; Boston MA) as described elsewhere (Simmons et al. 1989, 1900). TEF antisense and sense RNA probes contained 370 bp of $3^{\prime}$-untranslated sequence. TSH $\beta$ probes were synthesized from a pGEM vector as described elsewhere (Simmons et al. 1990). In situ hybridization studies of adult Sprague-Dawley rats were performed as described previously (Simmons et al. 1989) with an identical TEF antisense RNA probe.

\section{Protein preparations}

Proteins from all constructs were made using the T7 expression system with the bacterial strain pLysS (Studier et al. 1990). Crude bacterial extracts were used for all experiments and were prepared by using $30-\mathrm{ml}$ cultures induced at an $\mathrm{OD}_{600}$ of 1.0 with $0.5 \mathrm{~mm}$ IPTG for $4 \mathrm{hr}$. Cells were harvested by centrifugation, resuspended in one-fifth volume of buffer $\mathrm{Z}$ (Hoey and Levine 1988-except that $\mathrm{MgCl}_{2}$ was omitted-and sonicated for $30 \mathrm{sec}$. Cell debris was removed by centrifugation, and the soluble protein preparations were stored at $-20^{\circ} \mathrm{C}$. For the generation of rabbit antisera, TEF was extracted by the procedure of Hoey and Levine (1988) and purified by phosphocellulose chromatography as described elsewhere (Mangalam et al. 1989). TEF eluted from the phosphocellulose resin between 0.25 and $0.4 \mathrm{M}$ $\mathrm{KCl}$. In vitro transcriptions were performed in 50- $\mu$ l reaction volumes with an in vitro transcription kit (Stratagene) by using T7 RNA polymerase and $1 \mu \mathrm{g}$ of the appropriate $\mathrm{pET} 3 \mathrm{a}-\mathrm{TEF}$, $\mathrm{pET} 3 \mathrm{a}-\mathrm{C} / \mathrm{EBP}$, or linearized $\mathrm{pBKS}-\mathrm{DBP}$ vector according to the directions of the manufacturers. In vitro translations were performed in $25-\mu 1$ reaction volumes containing $70 \%$ nucleasetreated rabbit reticulocyte lysate (Promega), $100 \mu \mathrm{M}$ amino acids, and $1-\mu l$ aliquots of in vitro-transcribed RNA. Mobilityshift analyses were performed with $1.5-\mu 1$ aliquots of the translation reaction.

\section{DNA-binding studies}

DNA-binding studies were carried out by a standard mobilityshift assay as described previously (Mangalam et al. 1989). All binding assays were performed at room temperature for $20 \mathrm{~min}$ in a $20-\mu$ l volume of $20 \mathrm{~mm}$ HEPES ( $\mathrm{pH} 7.8), 1 \mathrm{~mm}$ EDTA, $0.1 \%$ NP-40, $15 \%$ glycerol, $3 \mu \mathrm{g}$ of poly[d(I-C)], $0.5 \mu \mathrm{g}$ of bovine serum albumin, and $0.25 \%$ dry nonfat milk (Carnation) with between 0.05 and $0.1 \mathrm{nM}$ of double-stranded oligonucleotides (see Figs. 7 and 8), radiolabeled using T4 kinase. One-fifth of each reaction was loaded on a $5 \%$ nondenaturing $0.5 \times$ TBE-polyacrylamide gel, electrophoresed at $300 \mathrm{~V}$ for $1.5 \mathrm{hr}$, and autoradiographed for $16 \mathrm{hr}$ at $-80^{\circ} \mathrm{C}$. DNase I footprinting was performed as described previously (Mangalam et al. 1989) with specific endradiolabeled promoter regions generated by a PCR strategy in which one of the input synthetic oligonucleotide primers was radiolabeled using T4 kinase (Bethesda Research Laboratory; Baltimore, MD) and $\left[\gamma^{-32}\right.$ P]ATP (New England Nuclear, Boston, MA). For methylation interference experiments, methylated oligonucleotides were selectively labeled at one end by using T4 kinase. Binding assays were performed as described above. Free and protein-bound DNAs were separated by electrophoresis on native polyacrylamide gels and subjected to piperidine cleavage after elution. Cleavage products were analyzed on $15 \%$ gels containing $7 \mathrm{M}$ urea.

\section{Cross-linking studies}

Glutaraldehyde cross-linking studies were performed with $9 \mu \mathrm{l}$ of crude bacterial extracts incubated for $3 \mathrm{~min}$ in $1 \times$ buffer $Z$ containing $0.01 \%$ glutaraldehyde $(20-\mu l$ total reaction volume). Reactions were stopped by the addition of $5 \mu \mathrm{l}$ of $5 \times$ Laemmli sample loading buffer containing Tris- $\mathrm{HCl}$ and $2 \% 2$-mercaptoethanol. Samples were size separated on a $12.5 \%$ SDS-polyacrylamide gel (Laemmli 1970), transferred to nitrocellulose, and immunoblotted essentially by the procedure of Towbin et al. (1979) with a rabbit polyclonal antisera directed against bacterially expressed wild-type TEF. TEF was detected with horseradish peroxidase (HRP)-conjugated protein A and HRP color development reagent (Bio-Rad; Richmond, CA) according to the directions of the manufacturer. Antisera were generated by immunizing a 3-pound female New Zealand white rabbit with 100 $\mu \mathrm{g}$ of purified TEF protein (amino acids 1-261) emulsified in 
Drolet et al.

Freund's complete adjuvant. The rabbit was subsequently boosted twice with similar protein preparations emulsified in Freund's incomplete adjuvant.

\section{Transient cotransfection assays}

A plasmid containing 5'-flanking information of the mouse TSH $\beta$ gene was a kind gift of Dr. J.A. Gurr. A fragment from -1228 to +8 (Gordon et al. 1988) was obtained by PCR with synthetic oligonucleotides containing XhoI or HindIII overhangs. This fragment was cloned in front of a firefly luciferase gene (deWet et al. 1987) as described previously (Nelson et al. 1988). Reporter plasmids containing either rat prolactin 5 'flanking information $(-422$ to +36$)$, rat growth hormone information $(-320$ to +8$)$, rat prolactin distal enhancer information $(-1830$ to $-1530 /-36$ to +33$)$, or multiple boxes of Prl-1P, palindromic $T_{3}$, or LexA elements (see Figs. 5 and 6) and the firefly luciferase gene were as described elsewhere (Glass et al. 1988; Nelson et al. 1988; Ingraham et al. 1990). African green monkey kidney cells (CV-1) were plated at a density of $2 \times 10^{5}$ per $60-\mathrm{mm}$ plate in Dulbecco's modified Eagle medium containing $10 \%$ newborn calf serum. One day later, cells were transfected with $1.7 \mu \mathrm{g}$ each of expression and reporter plasmid by using the calcium phosphate coprecipitation method (Chen and Okayama 1987). Cells were harvested $36-48 \mathrm{hr}$ after transfection and assayed for luciferase activity as described previously (deWet et al. 1987).

\section{Acknowledgments}

We thank Drs. Ron Emeson, Holly Ingraham, and Jeff Voss for helpful discussions and review of this manuscript; Dr. J.M. Mathis, Dr. Bogi Andersen, and Xi He for the gift of reagents; and Chuck Nelson for assistance with tissue culture. These studies were supported by a grant from the National Institute of Arthritis, Diabetes, and Digestive and Kidney Diseases (NIDDK-18477). D.W.D. and K.M.S. are predoctoral trainees in the Biomedical Sciences Program and are supported in part by NIDDK-07541. M.W. is a recipient of a postdoctoral fellowship from the Deutsche Forschungsgemeinschaft. M.G.R. is an investigator with the Howard Hughes Medical Institute.

The publication costs of this article were defrayed in part by payment of page charges. This article must therefore be hereby marked "advertisement" in accordance with 18 USC section 1734 solely to indicate this fact.

\section{References}

Akam, M. 1987. The molecular basis for metameric patterns in the Drosophila embryo. Development 101: 1-22.

Akira, S., H. Isshiki, T. Sugita, O. Tanabe, S. Kinoshita, Y. Nishio, T. Nakajima, T. Hirano, and T. Kishimoto. 1990. A nuclear factor for IL-6 expression (NF-IL6) is a member of the C/EBP family. EMBO J. 9: 1897-1906.

Birkenmeier, E.H., B. Gwynn, S. Howard, J. Jerry, J.I. Gordon, W.H. Landschulz, and S.L. McKnight. 1989. Tissue-specific expression, developmental regulation, and genetic mapping of the gene encoding CCAAT/enhancer binding protein. Genes \& Dev. 3: 1146-1156.

Brent, R. and M. Ptashne. 1985. A eukaryotic transcriptional activator bearing the DNA specificity of a prokaryotic repressor. Cell 43: 729-736.

Bodner, M., J.L Castrillo, L.E. Theill, T. Deerinck, M. Ellisman, and M. Karin. 1988. The pituitary-specific transcription factor GHF-1 is a homeobox-containing protein. Cell 55: 505-518.

Busch, S.J. and P. Sassone-Corsi. 1990. Dimers, leucine zippers and DNA-binding domains. Trends Genet. 6: 36-40.

Carr, F.E., L.R. Need, and W.W. Chin. 1987. Isolation and char- acterization of the rat thyrotropin $\beta$-subunit gene. $/$. Biol. Chem. 262: 981-987.

Chen, C. and H. Okayama. 1987. High efficiency transformation of mammalian cells by plasmid DNA. Mol. Cell. Biol. 7: 2745-2752.

Chirgwin, J.J., A.E. Przbyla, R.J. MacDonald, and R.J. Rutter. 1979. Isolation of biologically active ribonucleic acid from sources enriched in ribonuclease. Biochemistry 18: 5294-5299.

Curran T., M.B. Gordon, K.L. Rubino, and L.C. Sambucetti. 1987. Isolation and characterization of the c-fos (rat) cDNA and analysis of post-translational modification in vitro. Oncogene 2: 79-84.

Descombes, P., M. Chojkier, S. Lichtstelner, E. Falvey, and U. Schibler. 1990. LAP, a novel member of the C/EBP gene family, encodes a liver-enriched transcriptional activator protein. Genes \& Dev. 4: 1541-1551.

de Wet, J.R., K.V. Wood, M. deLuca, D.R. Helinski, and S. Subrimani. 1987. Firefly luciferase gene: Structure and expression in mammalian cells. Mol. Cell. Biol. 7: 725-737.

Elsholtz, H.P., H.J. Mangalam, E. Potter, V.R. Albert, S. Supowit, R.M. Evans, and M.G. Rosenfeld. 1986. Two different cis-active elements transfer the transcriptional effects of both EGF and phorbol esters. Science 234: 1552-1557.

Feinberg, A.P. and B. Vogelstein. 1983. A technique for radiolabeling DNA restriction endonuclease fragments to high specific activity. Anal. Biochem. 132: 6-13.

Friedman, A.D., W.H. Landschulz, and S.L. McKnight. 1989. CCAAT/enhancer binding protein activates the promoter of the serum albumin gene in cultured hepatoma cells. Genes \& Dev. 3: 1314-1322.

Gentz, R., F.J. Rauscher III, C. Abate, and T. Curran. 1989. Parallel association of Fos and Jun leucine zippers juxtaposes DNA binding domains. Science 243: 1695-1699.

Glass, C.K., J.M. Holloway, O.V. Devary, and M.G. Rosenfeld. 1988. The thyroid hormone receptor binds with opposite transcriptional effects to a common sequence motif in thyroid hormone and estrogen response elements. Cell 54: 313-323.

Gonzalez, G.A, K.K. Yamamoto, W.H. Fischer, D. Karr, P. Menel, W. Biggs III, W.W. Vale, and M.R. Montminy. 1989. A cluster of phosphorylation sites on the cyclic AMP-regulated nuclear factor CREB predicted by its sequence. Nature 337: 749-752.

Gordon, D.F., W.M. Wood, and E.C. Ridgway. 1988. Organization and nucleotide sequence of the gene encoding the $\beta$-subunit of murine thyrotropin. DNA 7: 17-26.

Hai, T., F. Liu, W.J. Coukos, and M.R. Green. 1989. Transcription factor ATF cDNA clones: An extensive family of leucine zipper proteins able to selectively form DNA-binding heterodimers. Genes \& Dev. 3: 2083-2090.

Hoey, T. and M. Levine. 1988. Divergent homeo box proteins recognize similar DNA sequences in Drosophila. Nature 332: $858-861$.

Hope, I.A. and K. Struhl. 1987. GCN4, a eukaryotic transcriptional activator protein, binds as a dimer to target DNA. EMBO I. 6: 2781-2784.

Ingraham, H.A., R. Chen, H.J. Mangalam, H.P. Elsholtz, S.E. Flynn, C.R. Lin, D.M. Simmons, L. Swanson, and M.G. Rosenfeld. 1988. A tissue-specific transcription factor containing a homeodomain specifies a pituitary phenotype. Cell 55: 519-529.

Ingraham, H.A., S.E. Flynn, J.M. Voss, V.R. Albert, M.S. Kapiloff, L. Wilson, and M.G. Rosenfeld. 1990. The POU-specific domain of Pit-1 is essential for sequence-specific, high affinity DNA binding and DNA-dependent Pit-1-Pit-1 interactions. Cell 61: 1021-1033.

Johnson, P.F. and S.L. McKnight. 1989. Eukaryotic transcrip- 
tional regulatory proteins. Annu. Rev. Biochem. 58: 799-839.

Jones, N. 1990. Transcriptional regulation by dimerization: Two sides of an incestuous relationship. Cell 61: 9-11.

Kouzarides, T. and E. Ziff. 1988. The role of the leucine zipper in the fos-jun interaction. Nature 336: 646-651.

Kunkel, T.A. 1985. Rapid and efficient site-specific mutagenesis without phenotypic selection. Proc. Natl. Acad. Sci. 82: 488-492.

Laemmli, U.K 1970. Cleavage of structural proteins during the assembly of the head of bacteriophage T4. Nature 227: 680-685.

Landschulz, W.H., P.F. Johnson, and S.L. McKnight. 1988a. The leucine zipper: A hypothetical structure common to a new class of DNA binding proteins. Science 240: 1759-1764.

Landschulz, W.H., P.F. Johnson, E.Y. Adashi, B.J. Graves, and S.L McKnight. 1988b. Isolation of a recombinant copy of the gene encoding C/EBP. Genes \& Dev. 2: 786-800.

Landschulz, W.H., P.F. Johnson, and S.L. McKnight. 1989. The DNA binding domain of the rat liver nuclear protein C/EBP is bipartite. Science 243: 1681-1688.

Li, S., E.B. Crenshaw III, E.J. Rawson, D.M. Simmons, L.W. Swanson, and M.G. Rosenfeld. 1990. Dwarf locus mutants lacking three pituitary cell types result from mutations in the POU-domain gene Pit-1. Nature 347: 528-533.

Lira, S.A., E.B. Crenshaw III, C.K. Glass, L.W. Swanson, and M.G. Rosenfeld. 1988. Identification of rat growth hormone genomic sequences targeting pituitary expression in transgenic mice. Proc. Natl. Acad. Sci. 85: 4755-4759.

Mangalam, H.J., V.R. Albert, H.A. Ingraham, M. Kapiloff, L. Wilson, C. Nelson, H. Elsholtz, and M.G. Rosenfeld. 1989. A pituitary POU domain protein, Pit-1, activates both growth hormone and prolactin promoters transcriptionally. Genes \& Dev. 3: 946-958.

Maniatis, T., E.F. Fritsch, and J. Sambrook. 1982. Molecular cloning: A laboratory manual. Cold Spring Harbor Laboratory, Cold Spring Harbor, New York.

Mitchell, P.J. and R. Tjian. 1989. Transcriptional regulation in mammalian cells by sequence-specific DNA binding protein. Science 245: 371-378.

Mueller, C.R., P. Maire, and U. Schibler. 1990. DBP, a liverenriched transcriptional activator, is expressed late in ontogeny and its tissue specificity is determined posttranscriptionally. Cell 61: 279-291.

Nelson, C., E.B. Crenshaw III, R. Franco, S.A. Lira, V.R. Albert, R.M. Evens, and M.G. Rosenfeld. 1986. Discrete cis-active genomic sequences dictate the pituitary cell type-specific expression in rat prolactin and growth hormone genes. $\mathrm{Na}$ ture 322: 557-562.

Nelson, C., V.R. Albert, H.P. Elsholtz, L.E.-W. Lu, and M.G. Rosenfeld. 1988. Activation of cell-specific expression of rat growth hormone and prolactin genes by a common transcription factor. Science 239: 1400-1405.

Oas, T.G., L.P. McIntosh, E.K. O'Shea, F.W. Dahlquist, and P.S. Kim. 1990. Secondary structure of a leucine zipper determined by nuclear magnetic resonance spectroscopy. Biochemistry 29: 2891-2894.

O'Shea, E.K., R. Rutkowski, and P.S. Kim. 1989. Evidence that the leucine zipper is a coiled coil. Science 243: $538-542$.

Poli, V., F.P. Mancini, and R. Cortese. 1990. IL-6DBP, a nuclear protein involved in interleukin- 6 signal transduction, defines a new family of leucine zipper proteins related to C/EBP. Cell 63: 643-653.

Ptashne, M. 1988. How eukaryotic transcriptional activators work. Nature 335: 683-689.

Ransone, L.J., J. Visvader, P. Sassone-Corsi, and I.M. Verma. 1989. Fos-Jun interaction: Mutational analysis of the leucine zipper domain of both proteins. Genes \& Dev. 3: 770-781.

Roman, C., J.S. Platero, J. Shuman, and K. Calame. 1990. lg/
EBP-1: A ubiquitously expressed immunoglobulin enhancer binding protein that is similar to C/EBP and heterodimerizes with C/EBP. Genes \& Dev. 4: 1404-1415.

Sakai, M., A. Okuda, I. Hatayama, K. Sato, S. Nishi, and M. Muranatsu. 1989. Structure and expression of the rat c-jun messenger RNA: Tissue distribution and increase during chemical hepatocarcinogenesis. Cancer Res. 49: 5633-5637.

Sanger, F., S. Nicklen, and A. Coulson. 1977. DNA sequencing with chain-terminating inhibitors. Proc. Natl. Acad. Sci. 74: 5463-5467.

Sassone-Corsi, P., L.J. Ransone, W.W. Lamph, and I.M. Verma. 1988. Direct interaction between fos and jun nuclear oncoproteins: Role of the "leucine zipper" domain. Nature 336: 692-695.

Schwind, J.L. 1928. The development of the hypophysis cerebri of the albino rat. Am. I. Anat. 41: 295-319.

Shupnik, M.A., E.C. Ridgway, and W.W. Chin. 1989. Molecular biology of thyrotropin. Endocr. Rev. 10: 459-475.

Simmons, D.M., J.L. Arriza, and L.W. Swanson. 1989. A complete protocol for in situ hybridization of messenger RNAs in brain and other tissues with radiolabeled single-stranded RNA probes. I. Histotechnol. 12: 169-181.

Simmons, D.M., J.W. Voss, H.A. Ingraham, J.M. Holloway, R.S. Broide, M.G. Rosenfeld, and L.W. Swanson. 1990. Pituitary cell phenotypes involve cell-specific Pit-1 mRNA translation and synergistic interactions with other classes of transcription factors. Genes \& Dev. 4: 695-711.

Singh, H., J.H. LeBowitz, A.S. Baldwin Jr., and P.A. Sharp. 1988. Molecular cloning of an enhancer binding protein: Isolation by screening of an expression library with a recognition site DNA. Cell 52: 415-429.

Struhl, K. 1989. Helix-turn-helix, zinc-finger, and leucine-zipper motifs for eukaryotic transcriptional regulatory proteins. Trends Biochem. Sci. 14: 137-140.

Studier, F.W. and B.A. Moffat. 1986. Use of bacteriophage T7 RNA polymerase to direct selective high-level expression of cloned genes. I. Mol. Biol. 189: 13-130.

Studier, F.W., A.H. Rosenberg, J.J. Dunn, and J.W. Dubendorff. 1990. Use of T7 RNA polymerase to direct expression of cloned genes. Methods Enymol. 185: 60-89.

Towbin, H., T. Staehelin, and J. Gordon. 1979. Electrophoretic transfer of proteins from polyacrylamide gels to nitrocellulose sheets: Procedure and some applications. Proc. Natl. Acad. Sci. 76: 4350-4354.

Turner, R. and R. Tjian. 1989. Leucine repeats and an adjacent DNA binding domain mediate the formation of functional cFos-cJun heterodimers. Science 243: 1689-1694.

Vinson, C.R., K.L LaMarco, P.F. Johnson, W.H. Landschulz, and S.L McKnight. 1988. In situ detection of sequence-specific DNA binding activity specified by a recombinant bacteriophage. Genes \& Dev. 2: 801-806.

Vogt, P.K, T.J. Bos, and R.F. Doolittle. 1987. Homology between the DNA-binding domain of the GCN4 regulatory protein of yeast and the carboxyl-terminal region of a protein coded for by the oncogene jun. Proc. Natl. Acad. Sci. 84: 3316-3319.

West, B.L, D.F. Catanzaro, S.H. Mellon, P.A. Cattini, J.D. Baxter, and T.L. Reudelhuber. 1987. Interaction of a tissue-specific factor with an essential rat growth hormone gene promoter element. Mol. Cell. Biol. 7: 1193-1197.

Wood, W.M., K.W. Ocran, M.Y. Kao, D.F. Gordon, L.M. Alexander, A. Gutierrez-Hartman, and E.C. Ridgway. 1990. Protein factors in thyrotropic tumor nuclear extracts bind to a region of the mouse thyrotropin $\beta$-subunit promoter essential for expression in thyrotropes. Mol. Endocrinol. 4: 1897-1904.

Ziff, E.B. 1990. Transcription factors: A new family gathers at the cAMP response site. Trends Genet. 6: 69-72. 


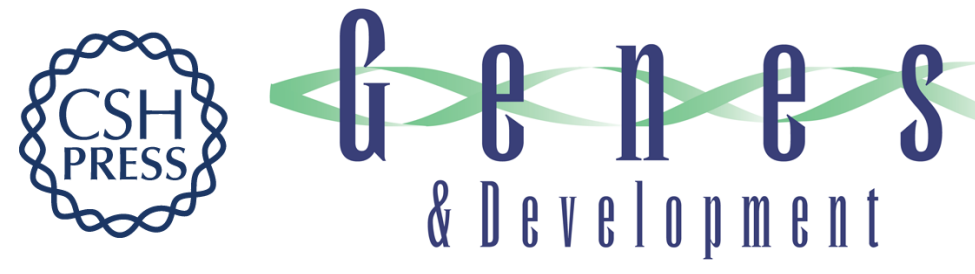

\section{TEF, a transcription factor expressed specifically in the anterior pituitary during embryogenesis, defines a new class of leucine zipper proteins.}

D W Drolet, K M Scully, D M Simmons, et al.

Genes Dev. 1991, 5:

Access the most recent version at doi:10.1101/gad.5.10.1739

References This article cites 63 articles, 29 of which can be accessed free at:

http://genesdev.cshlp.org/content/5/10/1739.full.html\#ref-list-1

License

Email Alerting Receive free email alerts when new articles cite this article - sign up in the box at the top Service right corner of the article or click here.

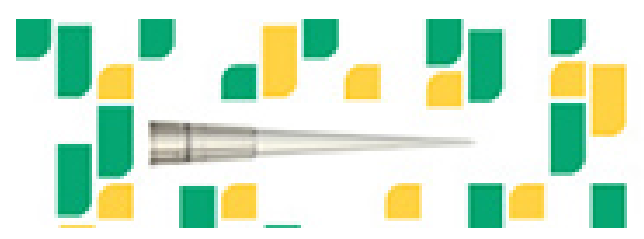

Focused on your science. 